\title{
A TAXONOMIC STUDY ON THE JAPANESE SPECIES OF CHAETOMIUM
}

\author{
SHUN-ICHI UDAGAWA \\ Division of Microbiology, National Hygienic Laboratory, Tokyo ${ }^{1}$ \\ Received for publication, Oct. 10, 1959.
}

In the field of industrial mycology, the genus Chaetomium is the most important of the members of Pyrenomycetes. All the species are best known as cellulolytic fungi (1). They are world-wide in distribution and upon the greatest variety of substrata, including grains, cereal products and various types of foodstuffs, pharmaceuticals, agricultural seeds, plant debris, textiles, fabrics, wood, paper, pulps, rubber, leather and other industrial materials, dung, and decaying vegetation in the field. They are also of widespread occurrence in soils from tropical and sub-tropical areas (2). Naturally, they bring about quite undesirable changes which cause spoilage in manufactured products of all kinds. Particularly, their chief economic significance is as very active agents of the degradation of cellulose materials. The comprehensive treatment on this subject has been recently reviewed by NoRD and Vitucci (3), Siu (4), and Siu and Reese (5). In Japan, Iwamoto et al. $(6,7)$ and NikaI (8) report Chaetomium species prevalent on bamboo-wares, with discussing methods for their control. The genus usually exists in nature as a true saprophyte. However, some species are weak parasites of plants and only one has been observed as pathogenic to human nails.

Little biochemical work with the genus has been reported. $C$. indicum is found to produce a tribasic acid $\mathrm{C}_{14} \mathrm{H}_{12} \mathrm{O}_{7}$ and two nitrogenous acids (9). The polyhydroxy-diphenyldiquinone, oosporein $\mathrm{C}_{14} \mathrm{H}_{10} \mathrm{O}_{8}$ has been isolated recently from $C$. aureum in at least three different laboratories $(10,11,12,13)$. Waksman and Bugie (14), Geiger (15), and Tveit (16) report the production of the antibiotic chetomin $\mathrm{C}_{16} \mathrm{H}_{17} \mathrm{O}_{4} \mathrm{~N}_{3} \mathrm{~S}_{2}$ from strains of $C$. cochliodes and others.

Unfortunately, an exhaustive survey of the Chaetomium has never been provided in Japan. The only one systematic report made from there (17) yields no information on the species which are prevalent. Therefore, the writer has made extensive collections from various sources and has discussed their taxonomical characteristics under the present system.

\section{GENERIC STATUS AND FRUITING STRUCTURES}

The genus Chaetomium is most closely related to Ascotricha $(18,19)$ and

1 2-203, Tamagawa-yoga-machi, Setagaya-ku, Tokyo, Japan. 
Lophotrichus (20). It has commonly been placed in the Chaetomiaceae of the Sphaeriales (21). NANNFEldt (22) placed the Chaetomiaceae to his Plectascales because of asci with walls that deliquesce very early and liberate masses of spores within the ascocarp. In a discussion of the morphological development for C. elatum, as well as Greis (23) had previously shown for C. globosum and $C$. bostrycodes, Moreau and Moreau (24) stated that the genus should be classified with the Sphaeriales. Munk (25) included it in the Melanosporaceae on the conception of MüLLER and ARx as an intermediate group between Plectascales and the typical ascohymenial Pyrenomycetes.

With few exceptions, the historical background of the genus has been adequately reviewed by CHIvers (18). He checked the propriety of the species published up to that time and listed 28 species as valid. In the same paper, he removed species having curious stiff or whip-like ampullate hairs to a genus Ascotricha. Since the appearance of ChIvers' monograph, Tschudy (26), Greathouse and Ames (27), Hughes (28), Skolko and Groves $(29,30)$, Batista and Pontual (31), Ames (32,33), La Touche (34), Omvik (35), and Sergejeva $(36,37,38)$ have contributed substantially to our knowledge of the genus. Furthermore, from the nomenclatural standpoints, Hughes (39) recently corrected some confusions. Among them, Skolko and Groves studied many of the previously known species very thoroughly and provided an excellent key which is constituted on the basis of differences in the characteristics of the perithecia, hairs, and ascospores. A total of 47 species are recognized in their monographic papers. The genus as treated here is as follows:

Сhaetomium Kunze ex Fries, Syst. Orb. Veg., 1: 156. 1825.

(Chaetomium Kunze, in Kunze \& Schm., Mykol. Hefte, 1: 16. 1817.)

Bolacotricha Berk. et Br., in Ann. Mag. Nat. Hist., I, 1: 257. 1838; Chaetomidium Zopf, in Nova Acta Leop. Carol. Akad., 42: 280. 1881; Bommerella March., in Bull. Soc. Roy. Botan. Belg., 24: 164. 1885; Vanhallia March., in Sacc., Syll. Fung., 15: 449. 1901.

Type, C. globosum Kunze ex Fr.

Mycelium tread-like, hyaline, septate, interwoven. Perithecia superficial, spherical to ovate or elongate, translucent to dark-colored and opaque, usually ostiolate, thin membranous, clothed with a dense mass of hairs. Terminal hairs slender, variable in pattern, straight to flexuous or coiled, simple or branched, forming a tuft above the perithecium. Lateral hairs short, usually straight or nearly so. Asci clavate or cylindric, 8-spored or rarely 4-spored, evanescent; paraphyses very reduced. Ascospores 1-celled, globose, ovate, ellipsoid, or sometimes angular, smooth, hyaline to mostly olivaceous, more or less compressed. Conidia occasionally of phialospores, borne on the side branchlets of aerial hyphae, 1-celled, small, globose to ovate, hyaline; chlamydospores rarely produced.

The perithecia, which have superficially developed on the mycelium or on the subiculum, fairly differ in shape and size. In most species they are 
spherical or subspherical to ovate. Nevertheless, at least 7 species produce elongate, sometimes short-necked ascocarps which are distinctive diagnostic characteristics. There is often considerable variation in the size within a species, due to differences in the nature of the substrate. The size of the perithecia is, therefore, an unreliable character in specific separation here, as the features in the rhizoidal attachment of the perithecium and the extrusion of the ascospores which has already been proved by SkoLko and Groves $(30)$ to be insignificant. The perithecial wall is in general darkcolored, thin membranous, and characteristically provided with a tuft of bristles.

The ascogonial development has been described by PAGE (40), GreIs (23), and Moreau and Moreau (24). More recently, Whiteside (41) reports two types of perithecial initials present in the 9 species examined by him. In the most common pattern, the ascogonium is a specialized bent hypha which twists about itself to form an irregular coil. In the second pattern, which is representative by $C$. brasiliense, the ascogonium typically forms a uniform spiral coil around the prominent ascogonial stalk. However, no particular taxonomic significance can be attributed to this character. Most of the species are homothallic. Of the 28 species tested, according to Tvert (16), 6 are found to be heterothallic.

The terminal hairs fall into 6 main groups in their pattern. Frequently they are long undulate, sinuous to loosely coiled or regularly spiral. In considerable species they are dichotomously branched, whereas in others they are straight to somewhat flexed or arcuate. In a few they are of reversed loops. Their features are not only of value in allocating the species in major sections but are often used for separating species within these sections. The diameter, which is sometimes used as an apparent diagnostic criterion, is constant within a fairly definite range for each species. In many cases, the walls are roughened with minute encrustments though various gradations from smooth to markedly granular are found.

On the other hand, the lateral hairs are of secondary importance because of the fact that they are generally indistinct and very difficult to apply for taxonomic separation. Ames (32) found that in C. seminudum the distinctive mycelial hairs, which closely resemble the lateral hairs, are formed from many of the vegetative hyphae on agar surface. Subsequently, Whiteside (41) has shown for $C$. brasiliense and $C$. aureum that this feature possibly might be regarded as a characteristic indicative of an isolate having perithecial initials of the $C$. brasiliense type. However, unrelated with the ascogonial pattern, the writer has been found it in C. murorum, C. subspirale, C. spirale, and $C$. brasiliense. It seems likely that the formation of mycelial hairs in these species is based on circumstantial conditions.

In most species the asci are clavate and 8-spored. In some species, especially those having terminal hairs contorted in reversed loops, they are cylindric. Furthermore, in C. tetrasporum it is 4 -spored. The walls of the 
VoL. 6

asci are very thin and almost immediately dissolved at maturity. This is considered to be an evolutionary development from Sphaeriales in which definite, functional asci occur. Whether paraphyses occur is doubtful. They have been described for a few species but very reduced.

With the certain exception of the terminal hairs, the ascospores provide more important characters for separating the species than any other taxonomic criteria. In general, the ascospores are 1-celled, lemon-shaped and darkcolored. In a few species, such as $C$. trigonosporum and $C$. quadrangulatum, they are uniquely angular. In still other species various figures from globose to nearly fusiform have been observed. The ascospore dimensions show a fairly consistent range of variation, hence afford a reasonable criterion for use in species identification.

The conidia produced on the side branchlets of aerial hyphae have been reported in $C$. elatum $(24,42)$. Its stage is of a phialospore-type. Although some species, such as $C$. $z o p f i$ Boul., were hitherto described as they accompany in Sporotrichum spp. as the imperfect stage, there are transferred to the genus Ascotricha at present (18). Occasionally the chlamydospores produce terminally or intercalary on the aerial hyphae. However, it is quite unavailable characters in distinguishing species.

\section{MATERIALS AND METHODS}

Of the 161 cultures used in this study, 132 have been isolated from various sources, the remaining cultures have been received from herbaria in Japan and elsewhere. All of them are on deposit at the Mycological Collection of the National Hygienic Laboratory (NHL). The writer is particularly indebted to Dr. J. W. Groves for his aid in securing several specimens. The following abbreviations are used for indicating the origin of cultures:

HUT: Faculty of Technology, Hiroshima University, Hiroshima.

IAM: Institute of Applied Microbiology, University of Tokyo, Tokyo.

IFO: Institute for Fermentation, Osaka.

NI: Nagao Institute, Tokyo.

OUT: Faculty of Technology, Osaka University, Osaka.

Most descriptions of the species are based upon observations of their growth habits on cellulose agar (43), which is composed of $10 \mathrm{~g}$ powdered

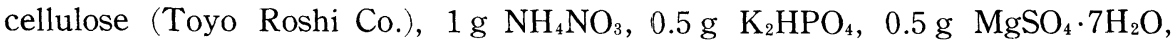
and $20 \mathrm{~g}$ agar per liter of infusion from $1 \mathrm{~kg}$ soil. The $\mathrm{pH}$ is adjusted to approximately 7.0 before sterilization. This medium is very useful for securing the development of perithecial structures. Modification of cellulose agar involving enrichment with 0.1 or sometimes 0.5 per cent yeast extract results in medium which is more favorable for certain species. Yeast extract agar (44) and potato-dextrose agar are subsequently used. Except in a few cases, such as $C$. elatum, these substrata are less diagnostic than cellulose agar. 
All the descriptions have been drawn up usually from Petri dish plates kept at $23-25^{\circ}$ for 3 weeks in artificial light.

\section{KEY TO THE SPECIES ${ }^{2}$}

The following key is a modification of the most recent classification of the genus given by Sкоцко and Groves $(30)$. In view of the writer's observation, the questionable value of perithecial characteristics as dependable taxonomic criteria has brought the primary use of the terminal hairs and ascospores for the separation of species.

Terminal hairs dichotomously branched $\ldots \ldots \ldots \ldots \ldots \ldots \ldots \ldots \ldots \ldots \ldots$ Group I

Terminal hairs arcuate $\ldots \ldots \ldots \ldots \ldots \ldots \ldots \ldots \ldots \ldots \ldots \ldots \ldots \ldots \ldots \ldots \ldots \ldots \ldots \ldots \ldots \ldots \ldots \ldots$ II

Terminal hairs straight to flexed $\ldots \ldots \ldots \ldots \ldots \ldots \ldots \ldots \ldots \ldots \ldots \ldots \ldots \ldots \ldots$ Group III

Terminal hairs long undulate, sinuous to loosely coiled $\ldots \ldots \ldots \ldots \ldots \ldots$. Group IV

Terminal hairs regularly spirally coiled $\ldots \ldots \ldots \ldots \ldots \ldots \ldots \ldots \ldots \ldots \ldots$ Group $\mathrm{V}$

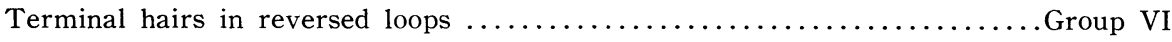

\section{GROUP I.}

A. Branches of terminal hairs essentially straight $\ldots \ldots \ldots \ldots \ldots \ldots \ldots \ldots \ldots \ldots$

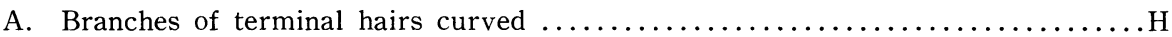

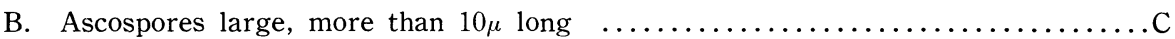

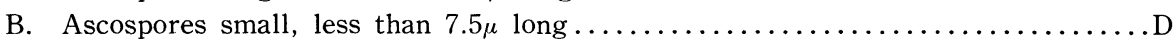

C. Terminal hairs dichotomously branched at right angles; ascospores lemon-

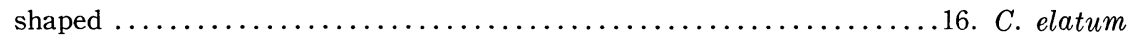

C. Branches of terminal hairs anastomosed; ascospores elliptical or spindleshaped $\ldots \ldots \ldots \ldots \ldots \ldots \ldots \ldots \ldots \ldots \ldots \ldots \ldots \ldots \ldots \ldots \ldots \ldots \ldots$ cuniculorum, ${ }^{*}$ C. rigidulum

D. Unbranched terminal hairs present at maturity, projecting above the mass

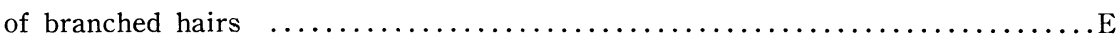

D. Unbranched terminal hairs usually lacking at maturity $\ldots \ldots \ldots \ldots \ldots \ldots \ldots$ F

E. Primary terminal hairs few, branched at wide angles, with long pointed tips, smooth or minutely roughened $\ldots \ldots \ldots \ldots \ldots \ldots \ldots \ldots$. C. dolichotrichum

E. Primary terminal hairs branched at acute angles, with short internodes and abrupt tips, coarsely roughened $\ldots \ldots \ldots \ldots \ldots \ldots \ldots \ldots \ldots \ldots$. C. funicola

F. Terminal hairs unequally thickened and constricted; ascospores globose or subglobose, $7-8 \mu$ diam.; thermophilic $\ldots \ldots \ldots \ldots \ldots \ldots \ldots \ldots$. thermophile

F. Primary terminal hairs uniform, not constricted; ascospores ovate, $5-7.5 \times$

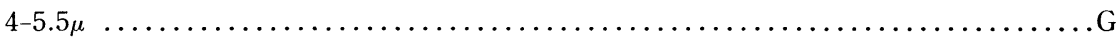

G. Primary terminal hairs numerous, regularly branched at right angles, forming a close network, with pointed tips $\ldots \ldots \ldots \ldots \ldots \ldots \ldots \ldots \ldots$. . indicum

G. Terminal hairs rigid with only a few short branches near the blunt tip .C. erectum

2 Asterisk indicates the species that appears to be difficult to separate in the key and may be later found to represent different forms of the same species. On account of the fact that either the systematic position is in doubt or the material is unobtainable for study, the following species are excluded in the key: Chaetomidium phyllactineum (42), Chaetomidium magnum (42), Chaetomium tortuosum (45), C. rufum (46), C. minutum (47), C. longicolleum (47), C. kurssanovianum (48), and C. prasinum (39). 
H. Terminal hairs straight with incurved branches, producing characteristic "crab-claw" effect C. cancroideum

H. Terminal hairs usually arcuate and branches extremely recurved.......

18. C. reflexum

\section{GROUP II.}

Terminal hairs with incurved tips; ascospores irregularly ovate....... . C. aureum Terminal hairs with 1-3 coiled tips; ascospores irregularly ovate ...4. C. trilaterale Terminal hairs with loosely circinate tips; ascospores lemon-shaped..C. turgidopilosum Terminal hairs with loosely circinate tips; ascospores fusiform, more than $11.5 \mu$ long

5. C. fusiforme

\section{GROUP III.}

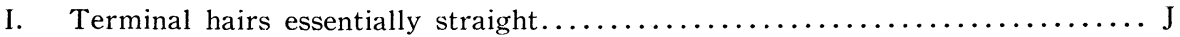

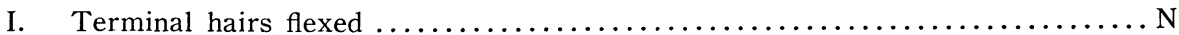

J. Perithecia elongate, vase-shaped; ascospores lemon-shaped $\ldots \ldots \ldots \ldots \ldots \ldots \ldots$

J. Perithecia globose or subglobose to ovate $\ldots \ldots \ldots \ldots \ldots \ldots \ldots \ldots \ldots \ldots \ldots \ldots$

K. Perithecia with elongated neck; terminal hairs broad, $6-7 \mu$ wide, with thread-like, wavy, collapsed branches near the tip ........... ampullare

K. Perithecia with short conic neck; terminal hairs slender, less than $4 \mu$ wide, sometimes branched at right angles

6. C. torulosum, ${ }^{*}$ C. seminudum, $*$ C. homopilatum

L. Ascospores triangular $\ldots \ldots \ldots \ldots \ldots \ldots \ldots \ldots \ldots \ldots \ldots \ldots$ trigonosporum

L. Ascospores ovate; terminal hairs persistently straight, rigid, spine-like,

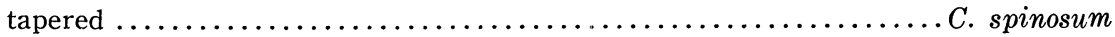

L. Ascospores ellipsoid; terminal hairs more or less flexed, untapered..........M

M. Terminal hairs of two types, the fuzzy mass of short fine hairs present, with irregularly branched or coiled tips................... cristatum

M. Terminal hairs never of two or more types, erect, unbranched or sometimes once divergently branched $\ldots \ldots \ldots \ldots \ldots \ldots \ldots \ldots \ldots$. . gracile n. sp.

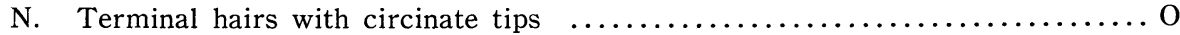

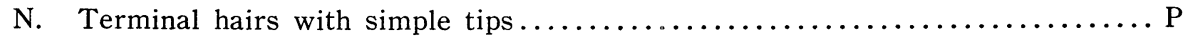

O. Terminal hairs with open recurved tips $\ldots \ldots \ldots \ldots \ldots \ldots \ldots . . . \ldots$. murorum

O. Terminal hairs with $2-3$ times recurved tips $\ldots \ldots \ldots \ldots \ldots \ldots \ldots$. circinatum

P. Terminal hairs of two types, the ornamentation of short branched hairs present around the ostiole; ascospores subglobose to ovate.....C. causiaeforme

P. Terminal hairs short awl-shaped, unbranched; ascospores ovate ....... f. fimeti

P. Terminal hairs long flexed, often with branches at wide angles; ascospores ellipsoid

9. C. atrobrunneum

\section{GROUP IV}

Q. Ascospores globose to subglobose, $15-16.5 \mu$ diam. $\ldots \ldots \ldots \ldots \ldots \ldots \ldots \ldots \ldots \ldots \ldots \ldots . . \ldots \ldots \ldots \ldots$. megalocarpum, ${ }^{*}$ C. atrosporum

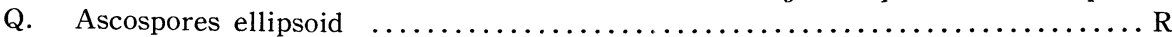

Q. Ascospores ovate or broadly ovate to lemon-shaped $\ldots \ldots \ldots \ldots \ldots \ldots \ldots \ldots$ S

R. Terminal hairs long undulate..19. C. undulatum, ${ }^{*}$ C. contortum, ${ }^{*}$ C. perlucidum

R. Terminal hairs with sinuous to large looping coils .........20. C. succineum

S. Ascospores more than $12 \mu$ long, lemon-shaped; terminal hairs loosely coiled 
S. Ascospores more than $8 \mu$ long but not over $12 \mu$; terminal hairs regularly

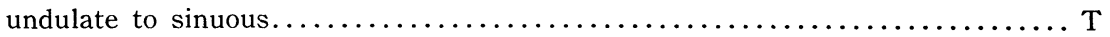

S. Ascospores less than $8.5 \mu$ long; terminal hairs irregularly undulate or

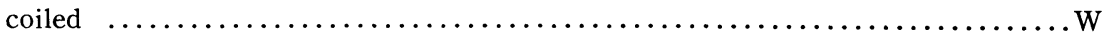

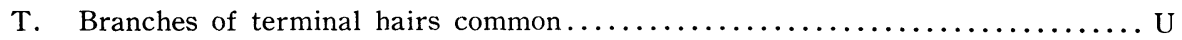

T. Branches of terminal hairs uncommon $\ldots \ldots \ldots \ldots \ldots \ldots \ldots \ldots \ldots \ldots . . .6$

U. Terminal hairs often compositely branched with acute angles; ascospores

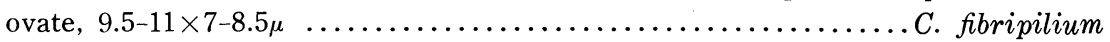

U. Terminal hairs branched with wide angles; ascospores lemon-shaped, 10$12 \times 8.5-10 \mu$

C. mollipilium

V. Ascospores broadly ovate, $9.5-12 \times 9-10.5 \mu \ldots \ldots \ldots \ldots \ldots \ldots$. C. olivaceum

V. Ascospores lemon-shaped, $8.5-10.5 \times 7-8.5 \mu \ldots \ldots \ldots \ldots \ldots \ldots \ldots \ldots$ 11. C. globosum, *C. bainierii (syn. C. setosum), *(haetomidium barbatum (49)

W. Ascospores ovate, $5-6 \times 4-5 \mu \ldots \ldots \ldots \ldots \ldots \ldots \ldots \ldots \ldots \ldots \ldots \ldots \ldots \ldots \ldots \ldots \ldots$ nigricolor

W. Ascospores lemon-shaped, 6-7.5 $\times 5-6 \mu$; perithecia narrow above ...C. sphaerale

W. Ascospores lemon-shaped, 7.5-8.5 $\times 5.5-6 \mu$; perithecia with densely entang-

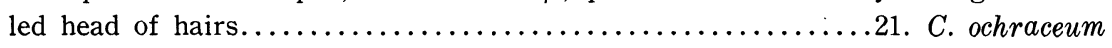

\section{GRouP V.}

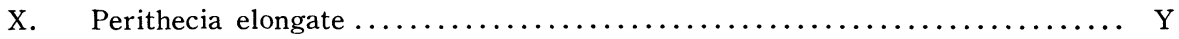

$\mathrm{X}$. Perithecia globose or subglobose to ovate $\ldots \ldots \ldots \ldots \ldots \ldots \ldots \ldots \ldots \ldots \ldots$

Y. Ascospores square ....................... quadrangulatum

Y. Ascospores subglobose, ovate, or lemon-shaped $\ldots \ldots \ldots \ldots \ldots \ldots \ldots \ldots \ldots$

Z. Perithecia barrel-shaped; terminal and lateral hairs both coiled, often irregular; branches absent $\ldots \ldots \ldots \ldots \ldots \ldots \ldots \ldots \ldots \ldots \ldots \ldots \ldots \ldots \ldots \ldots$. subspirale

Z. Perithecia cylindric; terminal hairs regularly coiled with few branches C. microcephalum

Z. Perithecia obclavate; branches of terminal hairs common .............AA

AA. Terminal hairs regularly coiled ..................... pachypodioides

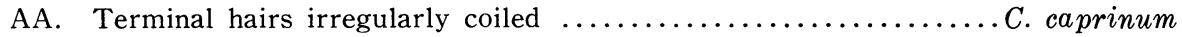

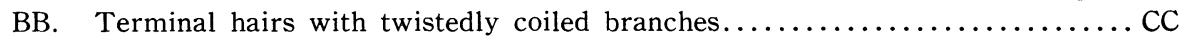

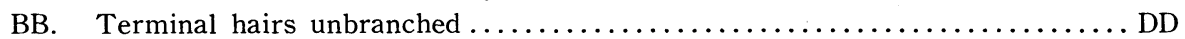

CC. Perithecia subglobose; asci 4 -spored.................. tetrasporum

CC. Perithecia ovate to ellipsoid; asci 8 -spored $\ldots \ldots \ldots \ldots \ldots \ldots$. angustispirale

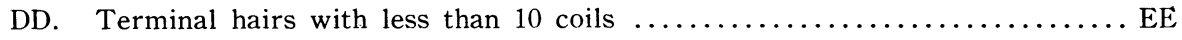

DD. Terminal hairs usually with more than 10 coils $\ldots \ldots \ldots \ldots \ldots \ldots \ldots \ldots \ldots$ JJ

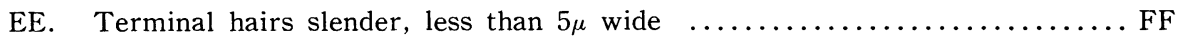

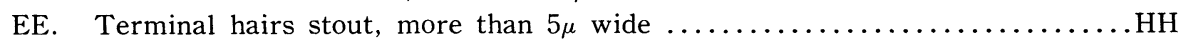

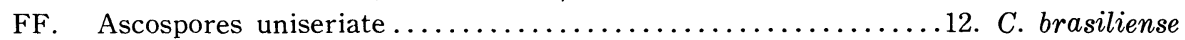

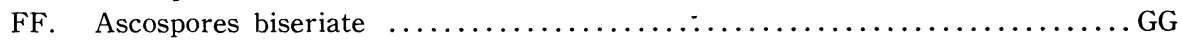

GG. Ascospores light-colored, subglobose, $6-7 \times 6-6.5 \mu \ldots \ldots \ldots \ldots \ldots \ldots \ldots$ $\ldots \ldots \ldots \ldots \ldots \ldots \ldots \ldots \ldots \ldots \ldots \ldots \ldots \ldots \ldots \ldots \ldots \ldots$ 13. C. bostrycodes, ${ }^{*} C$. comosum

GG. Ascospores dark-colored, ovate, $14-15 \times 11-12 \mu$; terminal hairs often irregularly coiled $\ldots \ldots \ldots \ldots \ldots \ldots \ldots \ldots \ldots \ldots \ldots \ldots \ldots \ldots \ldots \ldots \ldots \ldots \ldots \ldots$ sementrulli

GG. Ascospores dark-colored, ellipsoid, $10-13 \times 7-8.5 \mu$; terminal hairs uniformly coiled .C. gangligerum

HH. Ascospores light-colored, $7-8.5 \times 5.5-7 \mu$; terminal hairs wide spreading, with coils of constantly decreasing diam. 
HH. Ascospores dark-colored, $8.5-10 \times 7-8.5 \mu$; terminal hairs variable in pat-

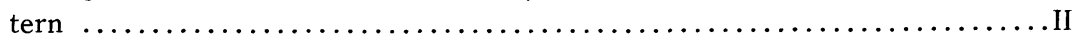

II. Straight terminal hairs present $\ldots \ldots \ldots \ldots \ldots \ldots \ldots \ldots \ldots \ldots \ldots \ldots$ angustum

II. Straight terminal hairs absent; undulate to loosely coiled hairs present 14. C. cochliodes

JJ. Terminal hairs about $5 \mu$ wide; ascospores ellipsoid, $12-14.5 \times 7-7.5 \mu \ldots$.

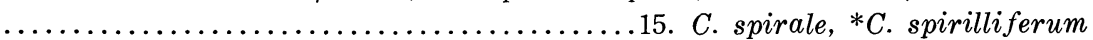

JJ. Terminal hairs about $5 \mu$ wide; ascospores lemon-shaped, $9-11 \times 8-9 \mu \ldots$.

JJ. Terminal hairs $9 \mu$ wide; ascospores ovate, $7-8.5 \times 5-7 \mu \ldots \ldots \ldots \ldots$. spirochaete GROUP VI.

KK. Terminal hairs of successively reversed spiral coils $\ldots \ldots \ldots \ldots \ldots \ldots$ tortile

KK. Terminal hairs of successively reversed loops with connecting arches ......LL

LL. Terminal hairs stout, about $15 \mu$ wide, with short arches........ contortum

LL. Terminal hairs slender, about $6-7 \mu$ wide, with short $\operatorname{arches} . \ldots \ldots \ldots$.

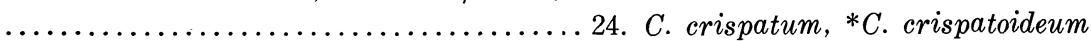

LL. Terminal hairs slender, about $6-8 \mu$ wide, with long arches .......... simile

1. Chaftomium funicola Cooke, in Grevillea, 1: 176. 1873; Palliser, in $\mathrm{N}$. Am. Flora, 3: 63. 1910; Chivers, in Mem. Torrey Botan. Club, 14: 176. 1915; Skolko \& Groves, in Can. J. Research, C, 26: 275. 1948. (Fig. 1) C. setosum (nec Wint., 1887, nec Bain., 1909) Ell. et Ev., 1897; C. bartholomaei Sacc. et Syd., 1899; Chaetomella cavallii Mattir., 1909.

Cultures on cellulose agar spreading broadly, greenish black. Perithecia dark olive brown, subglobose, $180-250 \mu$ in diam., ostiolate. Terminal hairs dark olive brown to black, forming a dense head, always of two kinds, (a) straight, unbranched, similar to the lateral hairs but coarsely roughened, narrowly projecting above the mass of ascospores and branched hairs, (b) dichotomously branched at acute angles, with the short internodes straight to slightly curved, $5.5-6 \mu$ wide at the base, coarsely roughened, septate, with abrupt tips, later formed hairs profusely branched, narrow, alternately constricted and inflated, slightly roughened. Lateral hairs dark olive brown to black below, fading above, straight, unbranched, tapered to collapsed tip, smooth to slightly roughened, $4-4.5 \mu$ wide at the base. Asci club-shaped, 8-spored, very evanescent. Ascospores olive green to dark blue green, ovate to ellipsoid, $5.5-6 \times 4-4.5 \mu$, more or less apiculate at the ends.

At $37^{\circ}$, growth is nil.

Habitat: On milled rices, Burma, China, Peru, Spain, and Thailand; hulled rice, Japan; seeds, Pisum sativum, Raphanus sativus, and Solanum melongena; soils, Tokyo and Saitama; catgut; pulp; cotton; Syntherisma leaves (NHL 2128-2146, 2209, 2253). Very common and widely distributed.

SPECIMEN EXAMINed: Culture from J. W. Groves (NHL 2107)

This species has been frequently confused with $C$. indicum but is apparently distinguished from it by the presence of acute branches with short internodes and blunt tips in the terminal hairs. 


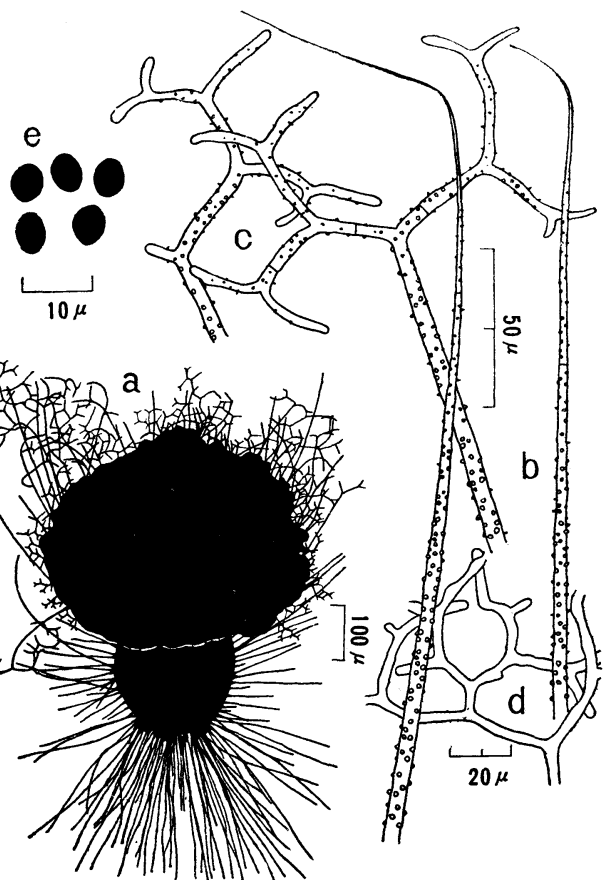

Fig. 1. C. funicola Cooke.

a. Perithecium. b. Unbranched terminal hairs. c. Branched terminal hairs. d. Secondary terminal hair. e. Ascospores.
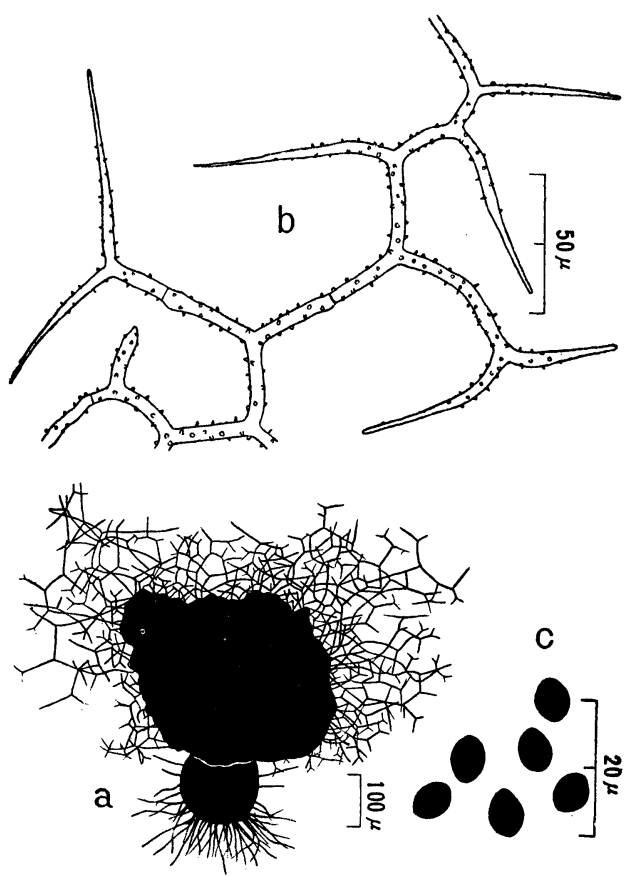

Fig. 2. C. indicum Corda.

a. Perithecium. b. Terminal hair. c. Ascospores.

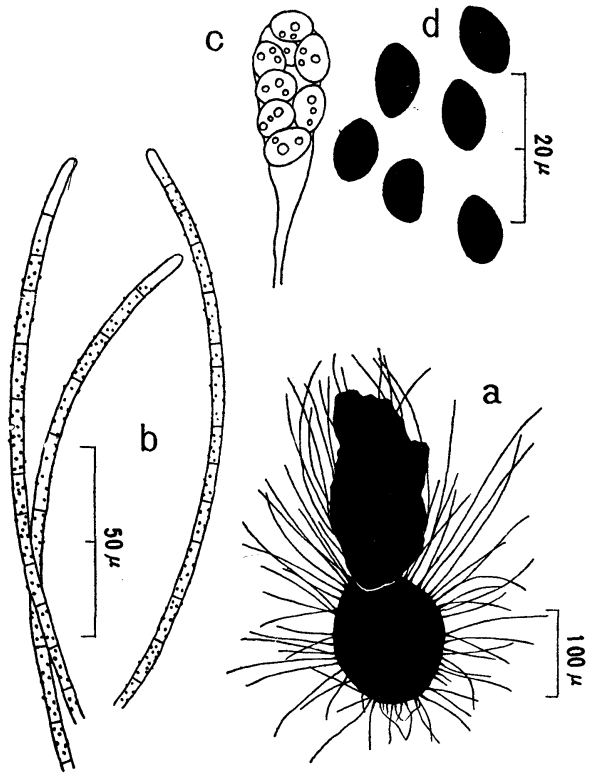

Fig. 3. C. aureum Chivers.

a. Perithecium. b. Terminal hairs. c. Ascus. d. Ascospores.

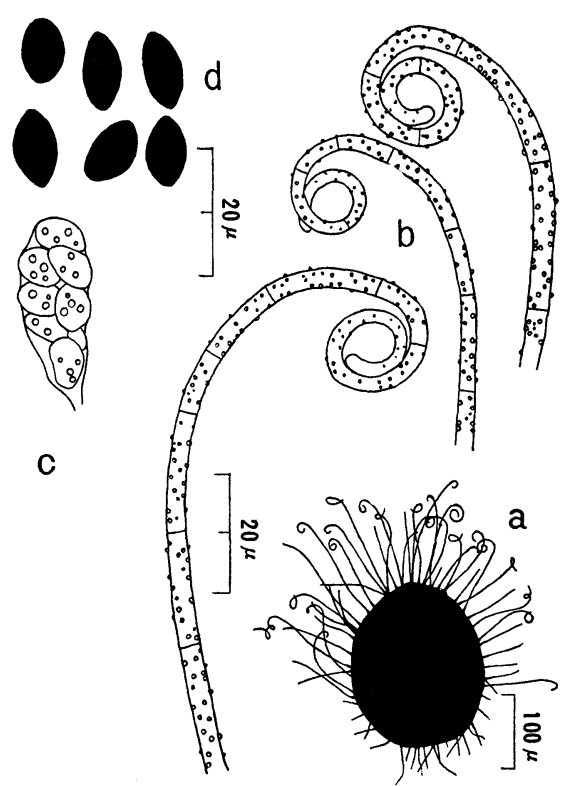

Fig. 4. C. trilaterale Chivers.

a. Perithecium. b. Terminal hairs. c. Ascus. d. Ascospores. 
2. Chaetomium indicum Corda, Icon. Fung., 4: 38. 1840; Chivers, in Mem. Torrey Botan. Club, 14: 178. 1915; Skolko \& Groves, in Can. J. Research, C, 26: 276. 1948. (Figs. 2, 25)

C. melioloides Cooke et Peck, 1875; C. setosum (nec Ell. et Ev., 1897, nec Bain., 1909) Wint., 1887.

Cultures on cellulose agar spreading broadly, dark olive green, with pale yellowish aerial hyphae. Perithecia olive brown, subglobose, $120-160 \mu$ in diam., ostiolate. Terminal hairs dark olive brown to black, at first forming a few unbranched hairs, then rapidly developing numerous dichotomously branched hairs, at maturity forming a close network, 4.5-6 $\mu$ wide, with branches regular at right angles and slightly reflexed, smooth or faintly roughened below, becoming coarsely roughened toward the fairly pointed tip, later formed hairs light olive brown, irregularly branched by acute angles, narrow, alternately constricted and inflated, finely roughened. Lateral hairs few, straight or slightly flexed, unbranched, dark brown, fading and tapering to collapsed tip, smooth, septate, $3-4.5 \mu$ wide at the base. Asci club-shaped, 8 -spored, very evanescent. Ascospores olive brown to olive green, ovate or unevenly ovate, $5-6.5(7.5) \times 4-5(5.5) \mu$, usually slightly apiculate at one or both ends.

At $37^{\circ}$, variable in different strains, but mostly restricted and abortive.

HABITAT: On milled rices, Japan and Burma; seeds, Beta vulgaris var. cicla, Glycine max, and Phaseolus angularis; soil, Saitama; wood-scobs; wheat, Japan (NHL 2223-2238). Widely distributed and very common.

Specimen examined: Culture from J. W. Groves (NHL 2222).

In the appearance of terminal hairs, the closest relative of the species is probably $C$. elatum, from which it is readily separated by means of its smaller ascospores.

3. Chaetomium aureum Chivers, in Proc. Am. Acad. Arts Sci., 48: 86.1912 \& in Mem. Torrey Botan. Club, 14: 174. 1915; Skolko \& Groves, in Can. J. Botany, 31: 785. 1953. (Fig. 3)

C. minimum van Beyma, 1944 (50).

Cultures on cellulose agar rather restrictedly growing, grayish olive green. Perithecia dark olive brown, subglobose to oval, $140-180 \times 120-160 \mu$, with wide ostiole. Terminal hairs yellowish brown, straight to commonly arcuate, with incurved blunt tips, 3-4 $\mu$ wide, finely roughened, septate. Lateral hairs similar but mostly straight, $2-3 \mu$ wide at the base. Asci clubshaped, 8-spored. Ascospores olive brown to olive green, irregularly ovate, sometimes flattened on one side, $8.5-10.5 \times 5.5-6 \mu$, subapiculate at one or both ends.

At $37^{\circ}$, poor growth.

НAвітAт: On seed, Beta vulgaris var. cicla; milled rice, Thailand; soils, Yamagata and Mie (NHL 2105-2108). Common.

Specimens eXamined: Cultures from J. W. Groves, NI, IFO, OUT, and HUT (NHL 2103-2104). 
This species is representative of a series based primarily upon the arcuated terminal hairs. The strain reported by Nishikawa $(10)$ as Chaetomidium sp. duplicates $C$. aureum in every respect.

4. Chaetomium trilaterale Chivers, in Proc. Am. Acad. Arts Sci., 48: 87. 1912 \& in Mem. Torrey Botan. Club, 14: 175. 1915; Skolko \& Groves, in Can. J. Botany, 31: 806. 1953 . (Figs. 4, 26)

C. cupreum Ames, 1949.

Cultures on cellulose agar growing restrictedly, brownish gray, with the surrounding agar obscurely tinted in grayish yellow brown shades. Perithecia at first translucent, becoming opaque, ripening late, mostly ovoid, $160-220 \times$ $120-180 \mu$, ostiolate, provided with short cirrhi. Terminal hairs arcuate from the base and incurved, at the apex 1-3 spirally convolute, $3-4 \mu$ wide at the middle of length, dark yellowish brown, septate, distinctly roughened. Lateral hairs straight or arcuate below, and loosely 1-2 spirally convolute at the apex, minutely roughened, 2.5-3 $\mu$ wide at the base. Asci club-shaped, 8spored. Ascospores olive green, irregularly ovate, often flattened on one side, 9-10.5 (12) $\times 6-7 \mu$.

At $37^{\circ}$, restricted, with abortive perithecia.

Habitat: On soils, Tokyo and Mie (NHL 2262-2264). Occasional.

SPECIMEN EXAMined: Culture from R. F. CAIN (NHL 2261).

Within the species $C$. trilaterale, individual strains vary appreciably in cultural characteristics, particularly with reference to pattern of the terminal hairs and size of the ascospores. NHL 2262 and 2263 are representative of such cultures, and appear to be transitional toward $C$. aureum or $C$. fusiforme. Strains, such as NHL 2261 and 2264, also differ in having yellowish red (bright copper colored) hairs. Ames (32) reports them as C. cupreum, which is a distinct species. However, Skolko and Groves (30) justifiably question the validity of establishing C. cupreum on the basis of hair color.

5. Chaetomium fusiforme Chivers, in Proc. Am. Acad. Arts Sci., 48: 87. 1912 \& in Mem. Torrey Botan. Club, 14: 175. 1915; Skolko \& Groves, in Can. J. Botany, 31: 793. 1953. (Fig. 5)

Cultures on cellulose agar rather restrictedly growing, black. Perithecia olive, subglobose to ovate, $100-120 \times 80-100 \mu$, with wide ostiole. Terminal hairs olive brown, arcuate with loosely circinate tips, $3-3.5 \mu$ wide, finely roughened, septate. Lateral hairs light olive brown, straight or slightly recurved at the apex, finely roughened, septate, $2-2.5 \mu$ wide at the base. Asci club-shaped, 8-spored. Ascospores olive to olive brown, fusiform, sometimes flattened on one side, $11.5-13 \times 4.5-6 \mu$, subapiculate at the ends.

At $37^{\circ}$, well growing.

HABITAT: On soil, Wakayama (NHL 2147). Rare.

This strain resembles rather closely $C$. aureum or some strains of $C$. trilaterale in the appearance of its terminal hairs but can be distinguished by the large fusiform ascospores instead of small subovate ones. 


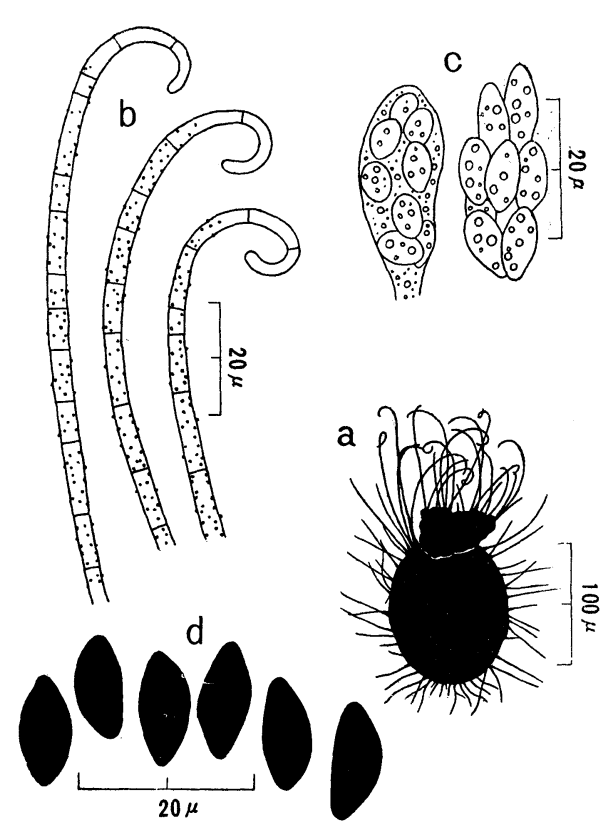

Fig. 5. C. fusiforme Chivers.

a. Perithecium. b. Terminal hairs. c. Asci. d. Ascospores.

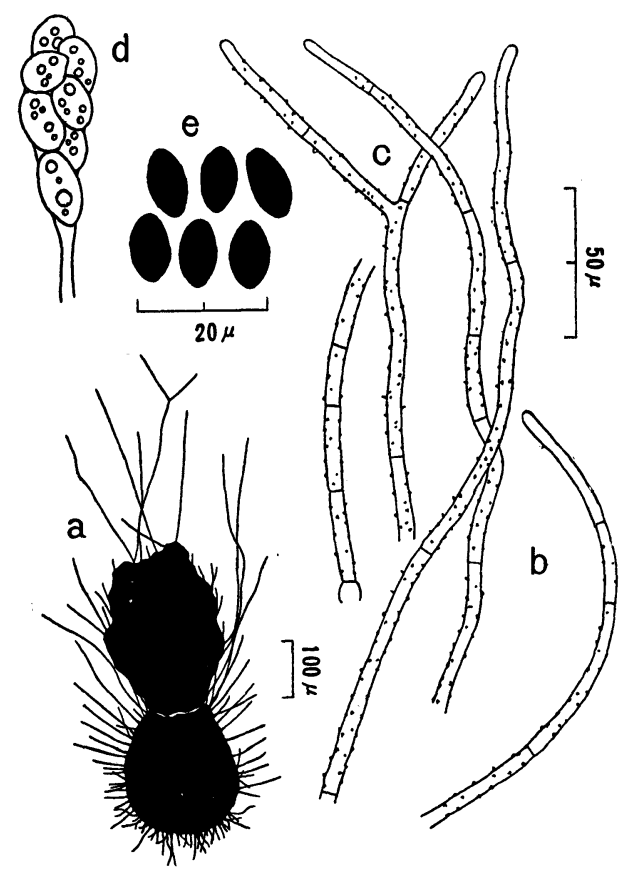

Fig. 7. C. gracile n. sp

a. Perithecium. b. Terminal hairs.

c. Branched terminal hair. d. Ascus.

e. Ascospores.

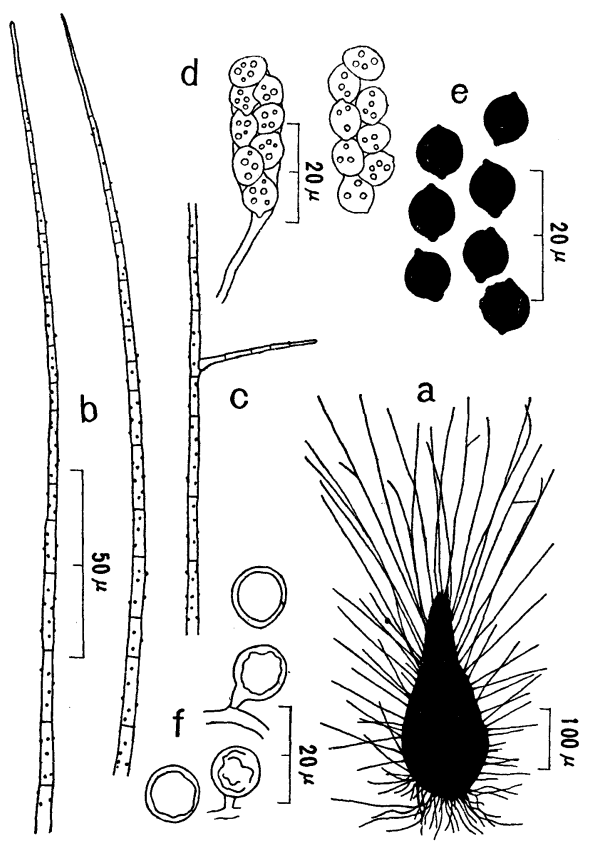

Fig. 6. C. torulosum Bainier.

a. Perithecium. b. Terminal hairs.

c. Branched terminal hair. d. Asci.

e. Ascospores. f. Chlamydospores.

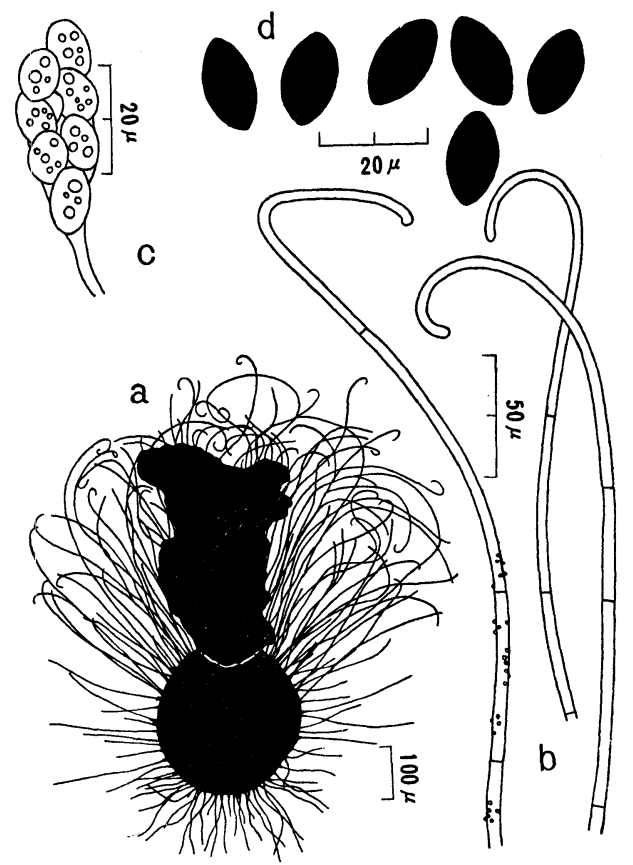

Fig. 8. C. murorum Corda.

a. Perithecium. b. Terminal hairs. c. Ascus. d. Ascospores. 
6. Chaetomium torulosum Bainier, in Bull. Soc. Mycol. France, 25: 224. 1909; Chivers, in Mem. Torrey Botan. Club, 14: 207. 1915; Skolko \& Groves, in Can. J. Botany, 31: 805. 1953. (Figs. 6, 27)

Cultures on cellulose agar moderately growing, black. Perithecia olive brown, vase-shaped, $250-320 \times 140-170 \mu$, ostiolate. Terminal hairs olive brown, straight, sometimes branched at right angles, gradually tapering to slender, collapsed or rounded tip, septate, often breaking at the septa, finely roughened, 3.5-4 $\mu$ wide at the base. Lateral hairs light olive brown, straight, short, $3-3.5 \mu$ wide at the base, with rounded tips. Asci club-shaped, 8-spored. Ascospores olive brown, lemon-shaped, 7.5-9 $\times 6-7.5 \mu$, apiculate at both ends. Chlamydospores laterally produced on the aerial hyphae, mostly globose, $7.5-12 \mu$ in diam., hyaline, smooth.

At $37^{\circ}$, growth is nil.

HABITAT: On wood-scobs; soil, Kagoshima (NHL 2259-2260). Widely distributed but not common.

The isolates from Japan are intermediate between $C$. torulosum and C. seminudum. Skolko and Groves (30) separate these two species on the basis of differences in the size of the perithecia, the appearance of the terminal hairs, and the shape of the ascospores. The ascospores of $C$. torulosum are 6-7.5 $\times 5-6 \mu$ while those of $C$. seminudum are $8-9.5 \times 7-8.5 \mu$. The ascospores of the former species are broadly ovoid in shape while those of the latter species have subglobose to broadly ovoid. Other distinguishing features of these species are not sufficiently fixed to be used in species separation. Hence, $C$. torulosum is only tentatively accepted as a valid taxon until additional information is obtained. Likewise, $C$. homopilatum is close to this species except for having somewhat smaller ascospores (35).

7. Chaetomium gracile Udagawa sp. nov. (Figs. 7, 28-31)

Perithecia obscure badia vel atra, subglobosa vel ovata, $180-240 \times 160-220 \mu$, ostiolata. Pili terminales longi primo arcuati, incurvati, maturitate recti vel paullo sinuati, simplices interdum sursum bifurcati, $4-5.5 \mu$ crassi, delicatim scabri, septati, apice obtusi. Pili laterales brevi, recti vel plus minusve incurvati, laeves, septati. Asci clavati, octospori, $46-48 \times 10-12 \mu$. Ascosporae olivaceo-brunneae, ellipsoideae, $10.5-12 \times$ $5.5-6 \mu$, utrinque paullo apiculatae.

Cultures on cellulose agar rather rapidly growing, black, with aerial hyphae sparse, reverse uncolored. Perithecia dark brown to black, superficial, subglobose to ovate, $180-240 \times 160-220 \mu$, with wide ostiole, firmly attached to the substratum by dark olive brown rhizoids, rapidly maturing in 2-3 weeks. Terminal hairs dark olive brown to black, arcuate from the base and incurved in the early stages, then gradually becoming long, straight or slightly sinuate at maturity, unbranched or sometimes once divergently branched near the tip, delicately roughened, septate, $4-5.5 \mu$ wide at the base, untapered, with blunt tips. Lateral hairs light brown, short, straight or somewhat incurved, smooth, septate, 3-4 $\mu$ wide at the base. Asci club-shaped, 8-spored, 46-48 $\times$ 10-12 . Ascospores olive brown, extruded in long cirrhi, up to $1-2 \mathrm{~mm}$. in 
length, ellipsoid, $10.5-12 \times 5.5-6 \mu$, faintly apiculate at the ends.

On Czapek agar growing rapidly, dark greenish gray, consisting of a thin basal felt with abundant aerial hyphae, more or less flocculent, perithecia densely clustered, slowly ripening and failing to produce characteristic terminal hairs within 3 weeks; reverse olive green.

On yeast agar dark bluish gray to black, reverse yellowish brown, otherwise similar to those on Czapek.

On potato-dextrose agar growing more rapidly than on Czapek, dark olive gray to black, reverse as on Czapek.

At $37^{\circ}$, well growing.

Habitat: On soil, Tsu, Mie Pref., Nov. 1958 (NHL 2251 TYPE, 2252). Type specimen has been deposited in the Mycological Collection of the Institute of Applied Microbiology, University of Tokyo, the Nagao Institute, Tokyo, and the Institute for Fermentation, Osaka.

The terminal hairs of this species closely resemble those of $C$. aureum until almost maturity, especially on common vegetative media. However, it may be easily distinguished from the latter by means of the ascospore shape. On the other hand, the ascospore size of this species falls within the range described for $C$. cristatum. Considering only the ascospores, therefore, $C$. gracile is near $C$. cristatum; in terminal hair characteristics the two species are unlike.

8. Сhaetomium murorum Corda, Icon. Fung., 1: 24. 1837; Chivers, in Mem. Torrey Botan. Club, 14: 166. 1915; Skolko \& Groves, in Can. J. Botany, 31: 797. 1953. (Fig. 8)

C. griseum Cooke, 1873; C. comatum var. helicotrichum Sacc., 1878; C. humanum Karst., 1888.

Cultures on cellulose agar ( 0.1 per cent yeast extract) growing moderately or rather rapidly, at first bluish gray, then dark bluish gray to bluish black or black in age, with the surrounding agar pale yellowish brown to pale brown. Perithecia dark-colored, globose to subglobose, 260-320 $\times 250-300 \mu$, ostiolate. Terminal hairs light brown to dark olive brown, slender, gracefully flexed, with open circinate, blunt tips, 5.5-6 $\mu$ wide, smooth or delicately roughened, septate. Lateral hairs olive brown below, fading above, straight to flexed, with pointed tips, smooth, septate, $4.5-5 \mu$ wide at the base. Asci club-shaped, 8-spored. Ascospores dark olive green, ellipsoid, 12-13.5 $\times 6-7.5 \mu$, subapiculate at one or both ends.

At $37^{\circ}$, growth is nil.

HabitaT: On milled rice, China; crude drug (NHL 2240-2241). Not common.

Specimen examined: Culture from R. F. Cain (NHL 2239).

CAIN's strain somewhat resembles C. circinatum because of the tendency of terminal hairs to show some recurved circinate character, but is otherwise typical.

9. Chaetomium atrobrunneum Ames, in Mycologia, 41: 641. 1949; Skolko \& 
Groves, in Can. J. Botany, 31: 784. 1953. (Fig. 9)

Cultures on cellulose agar moderately growing, at first gray to dark gray becoming black in age. Perithecia dark brown to brownish black, globose to subglobose, $150-200 \times 130-200 \mu$, with wide ostiole. Terminal hairs extremely long, slender, untapered or tapered only slightly to the blunt tip, straight to gracefully flexed, often branched at wide angles, light brown, mostly smooth, septate, $3-4 \mu$ in width. Lateral hairs similar but unbranched. Asci club-shaped, 8-spored. Ascospores olive brown to olive green, ellipticfusiform, $9-10.5 \times 4-5 \mu$.

At $37^{\circ}$, well growing.

HABITAT: On milled rice from Italy (NHL 2102). Rare.

Specimen EXAMined: Culture from J. W. Groves (NHL 2101).

The above findings differ from the original only in size of the perithecia. This species is easily recognized by the long flexuous hairs with wide-angled branches and elliptic-fusiform ascospores.

10. Снаетомium olivaceum Cooke et Ellis, in Grevillea, 6: 96. 1878; Palliser, in N. Am. Flora, 3: 60. 1910; Skolko \& Groves, in Can. J. Botany, 31: 798. 1953. (Fig. 10)

Cultures on cellulose agar spreading broadly, olive gray to dark olive gray. Perithecia dark olive brown, globose to subglobose or ovate, often bluntly pointed at the base, $300-360 \times 260-330 \mu$, ostiolate. Terminal hairs numerous and interwoven, olive brown, straight or flexed below, becoming long undulate above, with somewhat blunt or pointed tips, $4-4.5 \mu$ wide at the base, minutely roughened throughout, septate. Lateral hairs similar but only slightly flexed, 3-4 $\mu$ wide at the base. Asci club-shaped, 8-spored. Ascospores dark olive brown, broadly ovate to subglobose, $9.5-12 \times 9-10.5 \mu$, very finely apiculate at both ends.

At $37^{\circ}$, poor growth.

HABITAT: On milled rice, Burma; seed, Glycine max; soils, Saitama and Kagoshima; veneer sheets (NHL 2243-2248). Fairly common.

There is some question as to whether this species is distinct from $C$. globosum. Chivers (18) has considered it to be conspecific with C. globosum. According to SкоLко and Groves $(30)$, C. olivaceum may be distinguished from $C$. globosum on the basis of its generally larger microdimensions in the size of the perithecia and ascospores, and in the width of the terminal hairs. In the writer's findings, the only significant feature distinguishing the two is ascospore length and width.

11. Сhaetomium globosum Kunze ex Fries, Syst. Mycol., 3: 255. 1829; Chivers, in Mem. Torrey Botan. Club, 14: 190. 1915; Skolko \& Groves, in Can. J. Botany, 31: 794. 1953. (Fig. 11)

C. fieberi (non Fuckel, 1869) Corda, 1837; C. fieberi Corda var. chlorina Sacc., 1876; C. fieberi Corda subsp. saccardianum Bomm. et Rouss., 1884; C. lanosum Peck, 


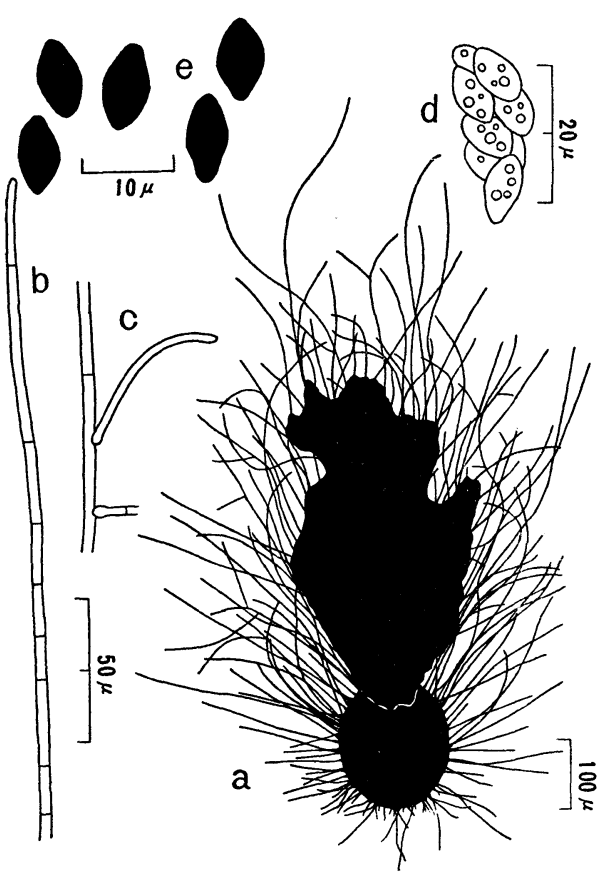

Fig. 9. C. atrobrunneum Ames. a. Perithecium. b. Terminal hair. c. Branched terminal hair. d. Ascus. e. Ascospores.

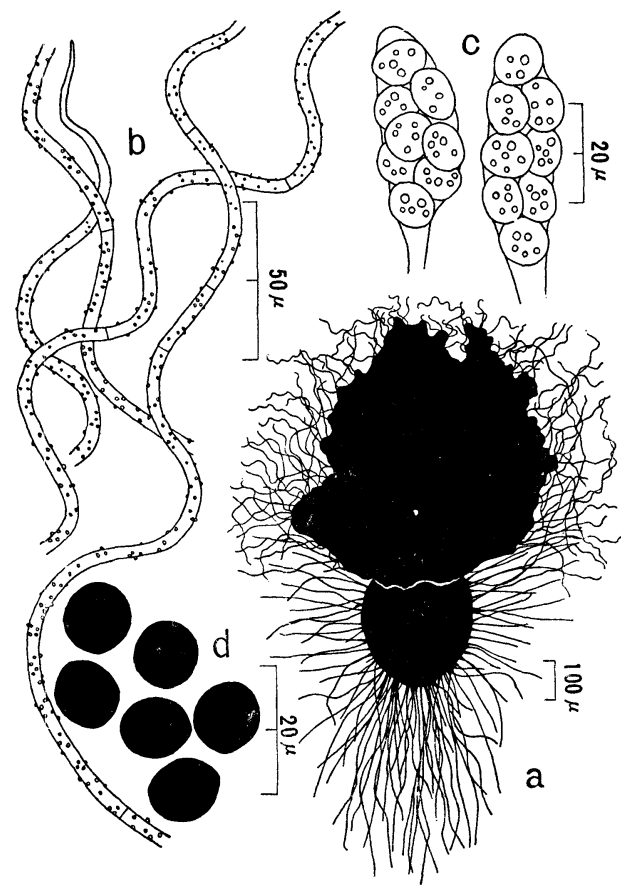

Fig. 10. C. oilvaceum Cooke et Ellis.

a. Perithecium. b. Terminal hairs. c. Asci. d. Ascospores.

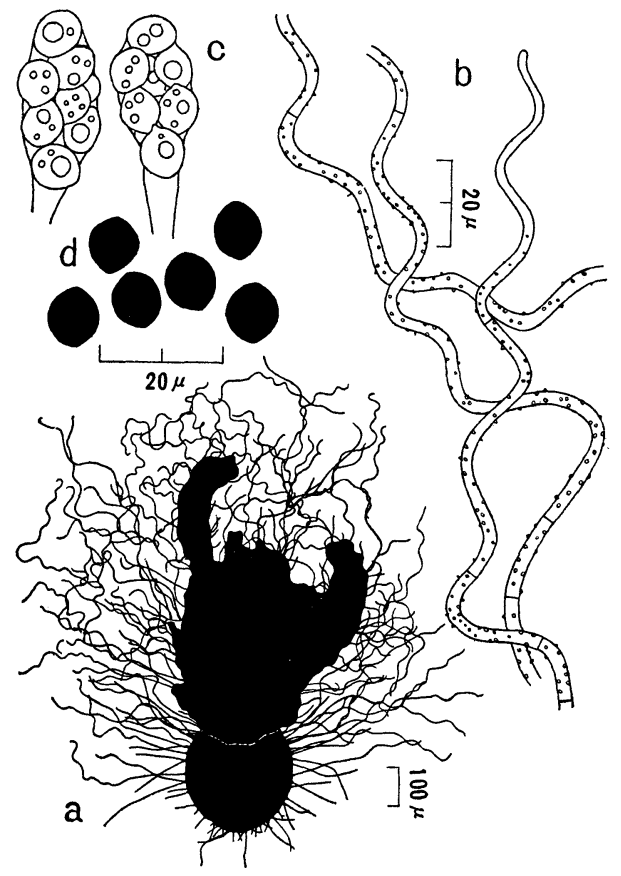

Fig. 11. C. globosum Kunze ex Fries.

a. Perithecium. b. Terminal hairs. c. Asci. d. Ascospores.
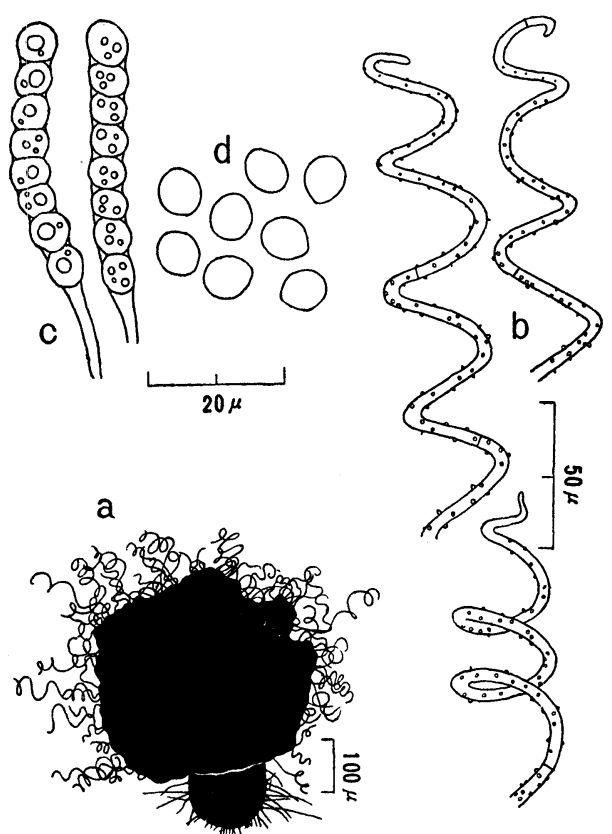

Fig. 12. C. brasiliense Batista et Pontual. a. Perithecium. b. Terminal hairs. c. Asci. d. Ascospores. 
1876; C. orientale Cooke, 1877; C. kunzeanum Zopf, 1881; C. kunzeanum var. fimicolum Bomm. et Rouss., 1884; C. kunzeanum var. chlorina Mich., 1909 (42); C. macrosporum Sacc. et Penzig, 1882; C. cymatotrichum Cooke, 1883; C. oospora Beauv., 1900; C. elasticae Koord., 1907; C. subterraneum Swift et Povah, 1929 (51); Chaetomidium japonicum Saito et Okazaki, 1939; C. deustum Bat. et Pontual, 1948.

Cultures on cellulose agar spreading broadly, variously colored in individual strains, olive gray, grayish olive green, dark olive green, and olive black; reverse usually uncolored. Perithecia dark olive to black, subglobose to ovate, often with pointed bases, mostly $240-350 \times 250-320 \mu$, ostiolate. Terminal hairs numerous, forming a densely interwoven mass, olive brown, flexuous from the base, usually becoming sinuous or very loosely coiled toward the ends, in some strains long undulate throughout, slender, 2.5-3.5 (4) $\mu$ wide, slightly tapering to pale rounded tip, minutely roughened, septate. Lateral hairs light olive brown, straight or slightly flexed to undulate, finally intermingled with the terminal hairs, 3-4 $\mu$ wide at the base. Asci clubshaped, 8-spored. Ascospores olive brown, lemon-shaped, 8.5-10.5 $\times 7-8.5 \mu$, mostly $9 \times 7.5 \mu$, subapiculate at both ends.

At $37^{\circ}$, poor growth.

Habitat: On hulled rice, Japan; milled rices, Burma, China, Formosa, Italy, Pakistan, and Thailand; margarine; dead leaves, Acer sp., Crinum asiaticum var. japonicum, Derris sinuata, Durio zibethinus, Santalum album, and Syntherisma sp.; seeds, Brassica campestris var. deutata, Brassica campestris var. pekinensis, Cucurbita moschata, Phaseolus vulgaris, Raphanus sativus, and Vicia faba; wheats, Japan and Canada; soils, Yamagata, Tokyo, Saitama, Mie, Wakayama, Yamaguchi, and Kagoshima; paper; pulp; veneer sheets; dungs, hare and rabbit (NHL 2158, 2165-2208, 2210, 2211, 2213, 2215-2220). Very abundant and widely distributed.

SPecimens examined: Cultures from J. W. Groves, IAM, NI, IFO, OUT, and HUT (NHL 2148-2150, 2152-2154, 2156, 2157, 2159, 2161-2164).

C. globosum is by far the most representative and the most variable species. According to CHIvers (18), morphological variation in C. globosum appears in the shape of the mature perithecia, the feature of the terminal hairs, and the shape and size of the ascospores. The ascospores in his sense are varied from broadly ovate or subglobose to lemon-shaped or fusiform, and $9.5-13 \times 6.3-9.5 \mu$ in size. However, if his description is accepted, $C$. globosum is too variable to be treated with a single species. Ascospore shape and size between $C$. globosum and its allied species cannot be entirely ignored and any intergradation enough to warrant specific unification does not appear. In present treatment the writer has more or less restricted the C. globosum concept with the characteristics described above. A strain from the type material of Chaetomidium japonicum is almost indistinguishable from $C$. globosum and should be regarded as a synonym. The cultures from IFO, labelled "C. sphaerospermum (Ascotricha chartarum)", and from NI, labelled "Chaetomidium barbatum", are also hardly separable from C. globosum.

12. Chaetomium brasiliense Batista et Pontual, in Bol. Sec. Agr. Ind. Com., Pernambuco, 15: 69. 1948; Skolko \& Groves, in Can. J. Botany, 31: 787. 
1953. (Figs. 12, 32)

C. hamatum Bat. et Pontual, 1948; C. repandum Bat. et Pontual, 1948; C. velutinum (non Ell. et Ev., 1885) Ames, 1949.

Cultures on cellulose agar growing rapidly, grayish green. Perithecia dark olive brown, subglobose to ovate, $150-200 \times 130-180 \mu$, ostiolate. Terminal hairs olive brown, flexed below, spirally coiled above with up to 5 (7) coils, with rounded or pointed tips, 3-4 $\mu$ wide, mostly fairly roughened, septate. Lateral hairs straight to more or less flexed, with blunt and rounded tips, $3 \mu$ wide, minutely roughened, septate. Asci cylindrical, 8-spored. Ascospores uniseriate, light olive brown, broadly ovate, $6-7 \times 5.5-6 \mu$ but in individual strains often larger, slightly apiculate at one end.

At $37^{\circ}$, rather restricted, immature.

HABITAT: On soils, Tokyo and Saitama (NHL 2114, 2115). Occasional.

SPECIMENS EXAMINed: Cultures from J. W. Groves (NHL 2111-2113).

This species is characterized by its spirally coiled hairs and uniseriate ascospores, which has been readily observed in all of the cultures listed above.

13. Chaetomium bostrycodes Zopf, in Sitz. Botan. Ver. Prov. Brandenb., 19: 173. 1877; Chivers, in Mem. Torrey Botan. Club, 14: 201. 1915; Skolko \& Groves, in Can. J. Botany, 31: 786. 1953. (Fig. 13)

C. caninum Ell. et Ev., 1888; C. formosum Bain., 1909; C. formosum var. ovatum Bain., 1909; C. formosum var. neglectum Bain., 1909.

Cultures on cellulose agar ( 0.1 per cent yeast extract) growing rapidly, gray. Perithecia dark olive brown to black, mostly ovate, $220-260 \times 200-250 \mu$, ostiolate. Terminal hairs dark olive brown, straight below, becoming spirally coiled above with up to 8 (10) diminishing coils, with untapered, rounded and hyaline tips, $4-4.5 \mu$ wide at the base, distinctly roughened upwards, septate. Lateral hairs olive brown, fading to collapsed tip, straight, roughened, septate, at the base $3.5-4 \mu$ wide. Asci club-shaped, 8-spored. Ascospores pale olive, subglobose to broadly ovate, very finely apiculate at one or both ends, $6-7 \times$ $6-6.5 \mu$.

At $37^{\circ}$, rather restrictedly growing, with immature perithecia.

HaBitat: On soil, Tokyo (NHL 2110). Rare.

Specimen examined: Culture from J. W. Groves (NHL 2109).

Variability in the perithecial size has been observed in individual strains, although the difference is not significant. In the characters of the terminal hairs it is related to $C$. spirochaete or $C$. cochliodes but is distinct on the basis of the small pale ascospores.

14. Chaetomium cochliodes Palliser, in N. Am. Flora, 3: 61. 1910; Chivers, in Mem. Torrey Botan. Club, 14: 204. 1915; Skolko \& Groves, in Can. J. Botany, 31: 789. 1953. (Fig. 14)

C. flexuosum Palliser, 1910.

Cultures on cellulose agar spreading broadly, dark olive green to dark olive gray. Perithecia dark olive brown to black, subglobose, $300-360 \times 260$ - 


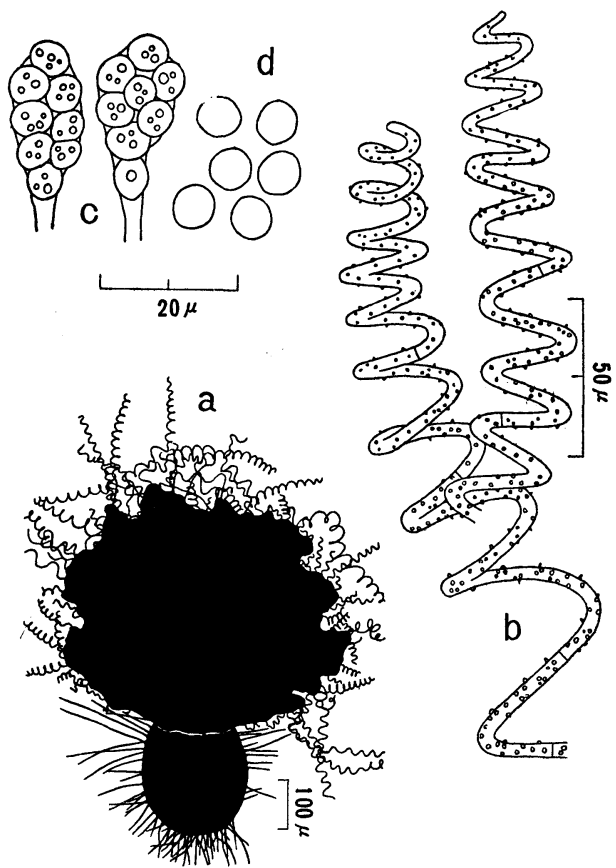

Fig. 13. C. bostrycodes Zopf.

a. Perithecium. b. Terminal hairs. c. Asci. d. Ascospores.

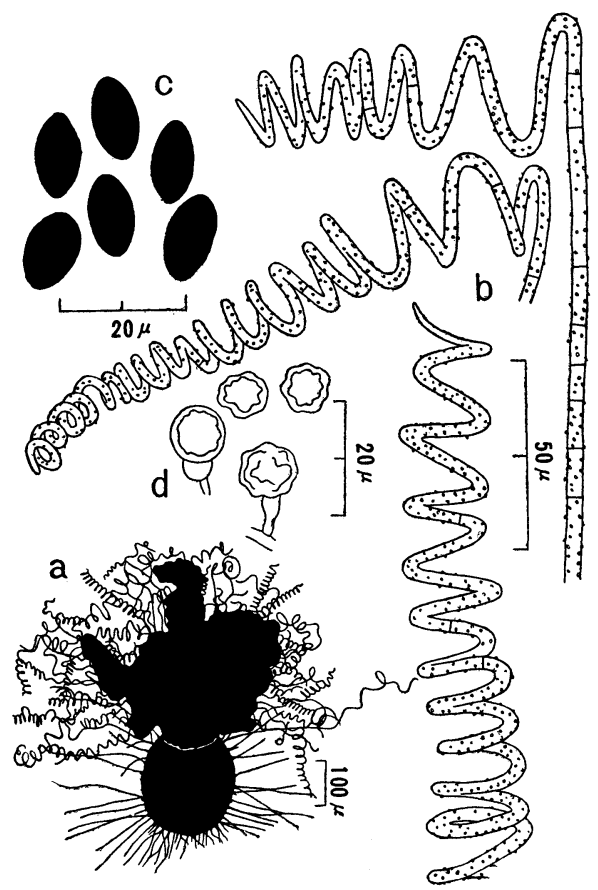

Fig. 15. C. spirale Zopf.

a. Perithecium. b. Terminal hairs.

c. Ascospores. d. Chlamydospores.

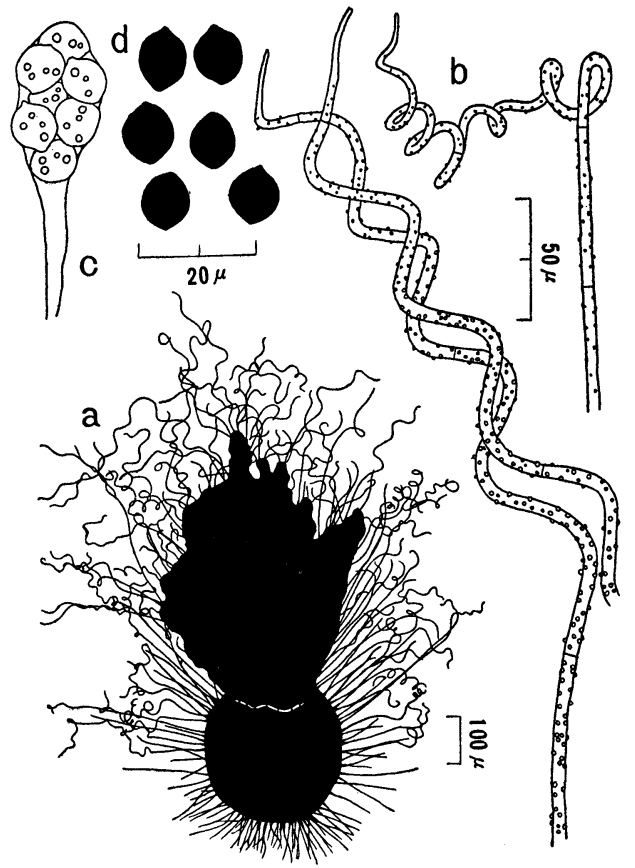

Fig. 14. C. cochliodes Palliser.

a. Perithecium. b. Terminal hairs, c. Ascus. d. Ascospores.

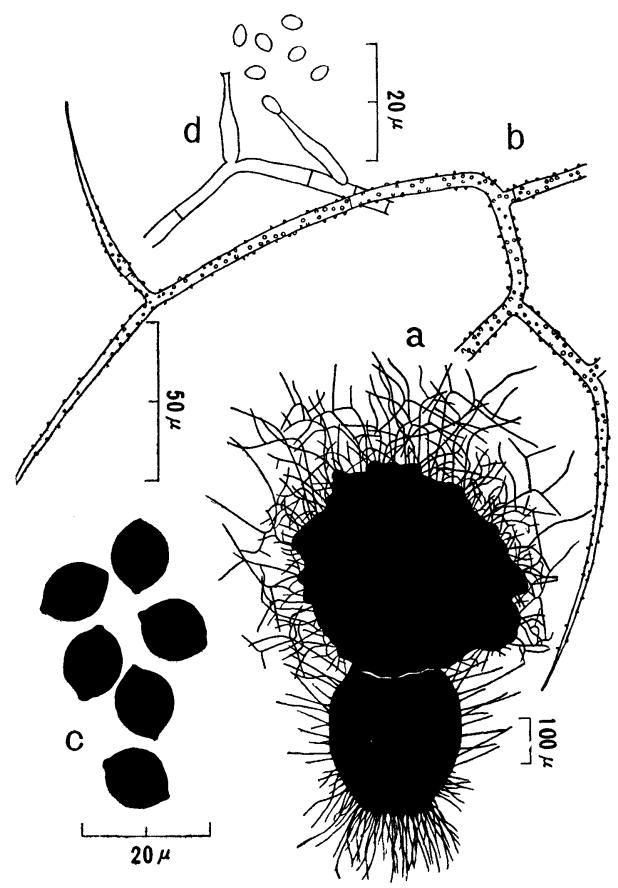

Fig. 16. C. elatum Kunze ex Fries.

a. Perithecium. b. Terminal hair. c. Ascospores. d. Phialides and conidia. 
$340 \mu$, ostiolate. Terminal hairs dark olive brown, at first straight below and sinuous above, at maturity in two types, (a) straight below, spirally coiled above with 3-5 coils, stout, coarsely roughened, obscurely septate, 5-6 $\mu$ wide at the base, and (b) slender, varied from irregularly twisted or undulate to loosely coiled with up to 7 coils, rather light-colored, minutely roughened, $3-3.5 \mu$ wide at the base. Lateral hairs dark olive brown, straight or flexed, gradually intermingled with the terminal hairs, roughened, septate, 4.5-5 $\mu$ wide at the base. Asci club-shaped, 8-spored. Ascospores dark olive brown, lemon-shaped, $9-10.5 \times 7.5-8.5(9) \mu$, apiculate at both ends.

At $37^{\circ}$, growth is nil.

Haвitat: On seed, Beta vulgaris var. cicla; soils, Tokyo and Kagoshima; Pinus roots (NHL 2118-2123, 2214). Widely distributed and fairly common.

SPecimens examined: Cultures from J. W. Groves and IFO (NHL 2116, 2117, 2155).

C. cochliodes is probably most closely related to $C$. globosum, which it resembles in many of its microscopic features. It differs from the latter by having broader terminal hairs and somewhat larger ascospores. Furthermore, the appearance of terminal hairs occurred on young perithecia is the character which separates it from $C$. globosum. Two specimens received from IFO, labelled " $C$. globosum" and " $C$. lusitanicum" respectively, are typical $C$. cochliodes.

15. Снаetomium spirale Zopf, in Nova Acta Leop. Carol. Akad., 42: 275. 1881; Sergejeva, in Not. syst. Sect. crypt. Inst. botan. Acad. Sci. U.S.S.R., 11: 105. 1956. (Figs. 15, 33-35)

Cultures on cellulose agar growing rapidly, dark greenish gray (slate olive). Perithecia dark olive brown to black, globose to subglobose, 160-250 $\times 140-240 \mu$, ostiolate. Terminal hairs olive brown, straight below, mostly spirally coiled above with $8-20$ or more coils, $35-45 \mu$ in diam., close and of uniform diameter, sometime sinuous to loosely or irregularly coiled with diminishing coils, 3.5-4 (4.5) $\mu$ in thickness, finely roughened throughout, obscurely septate, with rounded tips. Lateral hairs olive brown, straight, finely roughened, septate, $3-3.5 \mu$ wide at the base, fading and tapering to long tip. Asci club-shaped, 8-spored. Ascospores dark olive green to olive, ellipsoid, $12-14.5 \times 7-7.5 \mu$, faintly apiculate at one or both ends. Chlamydospores hyaline to pale yellow, apical, globose, $7.5-10.5 \mu$ in diam., warty, thick-walled.

At $37^{\circ}$, rapidly growing but abortive, with abundant chlamydospores.

HABITAT: On soils, Shizuoka and Kagoshima (NHL 2254-2256). Widely distributed but not common.

The above description of the Japanese isolates is somewhat atypical but may be easily distinguished from $C$. spirochaete by its longer spirally coiled terminal hairs and ellipsoid ascospores. Since Chivers (18) reduced $C$. spirochaete to synonymy with $C$. spirale, there has been considerable confusion concerning the identify of these species. Very recently, Sergejeva (37) pointed 
out the cause of the confusion and re-established $C$. spirochaete on the basis of the additional argument for U.S.S.R. material. The writer believes that Sergejeva is quite justified in considering these as two distinct species.

\section{SPECIES NOT FOUND IN JAPAN, BUT WHICH HAVE BEEN MAINTAINED AS LABORATORY CULTURES}

16. Сhaetomium elatum Kunze ex Fries, Syst. Mycol., 3: 254. 1829; Chivers, in Mem. Torrey Botan. Club, 14: 180. 1915; Skolko \& Groves, in Can. J. Research, C, 26: 272. 1948. (Fig. 16)

C. comatum (Tode) Fr., 1829; Psilonia cylindrica (Pers.) Fr., 1832; C. pannosum Wallr., 1833; Sphaeria chaetomium (non Corda, 1838) Lib., 1837; Chloridium ovoideum Corda, 1837; C. lageniforme Corda, 1837; C. affine Corda, 1840; Chloridium cylindricum (Pers.) Rabenh., 1844; C. graminis Rabenh., 1851; C. graminicolum Fuckel, 1863; C. fieberi (non Corda, 1837) Fuckel, 1869; C. libertii Roum. et Pat., 1883; C. velutinum (non Ames, 1949) Ell. et Ev., 1885; C. atrum var. distinctum Roum., 1886; C. fieberi Corda f. chartarum Roum., 1891; C. glabrescens Ell. et Ev., 1893.

Cultures on yeast agar spreading broadly, dark greenish gray to greenish black, consisting of a matted basal felt, with aerial hyphae white to pale yellow, perithecia slowly developing on the colony surface; reverse pale yellow; conidial fructifications very simple, consisting of single phialides borne irregularly on aerial hyphae; phialides sessile, slender, $12-20 \times 2-2.5 \mu$, tapering gradually to the apex; conidia of phialospore-type, ovate to ellipsoid, 3-3.5 $\times$ $2-2.5 \mu$, often pointed at one end, hyaline, smooth, clustered at the tip of phialides. Perithecia black, ovate, $350-450 \times 300-400 \mu$, ostiolate. Terminal hairs dark olive brown; unbranched hairs obscure; branched hairs straight below, several times dichotomously branched above, with branches at right angles and often reflexed (not strictly dichotomous), coarsely roughened throughout, stiff, 4.5-7.5 $\mu$ wide, with long pointed tips; later formed hairs similar, but with branches at acute angles, more narrow and sinuous than those of the former. Lateral hairs dark olive brown, straight or flexed, unbranched, $4-4.5 \mu$ wide at the base, with rounded tips, roughened, obscurely septate. Asci club-shaped, 8-spored, very evanescent. Ascospores dark olive brown, lemon-shaped, $10.5-12.5 \times 8.5-9 \mu$, apiculate at both ends.

At $37^{\circ}$, growth is nil.

Specimen examined: Culture from J. W. Groves (NHL 2126).

The extremely large ascospores clearly separate this fungus from the other species with dichotomously branched hairs.

17. Сhaetomium dolichotrichum Ames, in Greathouse \& Ames, Mycologia, 37: 145. 1945; Skolko \& Groves, in Can. J. Research, C, 26: 274. 1948. (Figs. 17, 36)

Cultures on cellulose agar spreading broadly, grayish olive green to dark olive green. Perithecia dark olive to black, globose to subglobose, 100-150 in diam., ostiolate. Terminal hairs in two types; primary hairs dark olive 
brown, varying from slender, unbranched to few times divergently dichotomously branched with wide angles, extending beyond the mass of secondary hairs and ascospores, with tips pointed and often collapsed, 4.5-5.5 $\mu$ wide at the base, smooth or minutely roughened, remotely septate; secondary hairs olive brown, several times dichotomously branched at somewhat acute angles, forming a dense mass about the base of the primary hairs, $2.5-3 \mu$ wide at the base, minutely roughened, septate. Lateral hairs few, olive brown below, fading above, straight or slightly curved, $3 \mu$ wide at the base, with blunt or pointed tips, mostly smooth, septate. Asci club-shaped, 8-spored, very evanescent. Ascospores light olive brown, ovate to ellipsoid, 6-6.5 $\times 3.5-4.5 \mu$, sometimes delicately apiculate at the ends.

At $37^{\circ}$, growth is nil.

Specimen examined: Culture from J. W. Groves (NHL 2125).

As Skolko and Groves (29) have concluded, the distinctive primary terminal hairs separate this from $C$. funicola or $C$. indicum.

18. Chaetomium reflexum Skolko et Groves, in Can. J. Research, C, 26: 279. 1948. (Fig. 18)

Cultures on cellulose agar growing rapidly, at first light gray, then becoming black in age. Perithecia black, ovate to subglobose, $100-120 \mu$ in diam., ostiolate. Terminal hairs dark olive brown, arcuate with short, stout, extremely recurved, dichotomous branches, often alternately constricted and inflated, with blunt tips, fairly roughened in upper part, septate, $4.5-5 \mu$ wide at the base; sometimes a few unbranched hairs projected beyond the dense mass of branched hairs and ascospores, tapering to slender, smooth tip. Lateral hairs light-colored, few, short, straight, with rounded tips, 2-2.5 wide. Asci club-shaped, 8-spored, conspicuously evanescent. Ascospores light olive brown, ovate, $5-6 \times 4-4.5 \mu$, often faintly apiculate at the ends.

At $37^{\circ}$, growth is nil.

Specimen examined: Culture from J. W. Groves (NHL 2250).

The findings agree in most respects with the typical description except the presence of a few unbranched terminal hairs. The branched terminal hairs of this species are distinctive.

19. Снаетомium undulatum Bainier, in Bull. Soc. Mycol. France, 25: 208. 1909. (Figs. 19, 37)

Cultures on cellulose agar ( 0.5 per cent yeast extract) growing rapidly, bluish gray, colonies in reverse pale yellow. Perithecia dark bluish gray to black, ovate, $220-300 \times 140-220 \mu$, ostiolate. Terminal hairs light olive brown to olive brown, straight below, becoming gracefully undulate above, unbranched, tapering to narrow rounded or pointed tip, finely roughened to smooth near the apex, septate, $4-4.5 \mu$ wide. Lateral hairs light-colored, straight or slightly flexed, tapering to long collapsed tip, finely roughened, obscurely septate, $2.5-3 \mu$ wide at the base. Asci club-shaped, 8-spored. Ascospores 


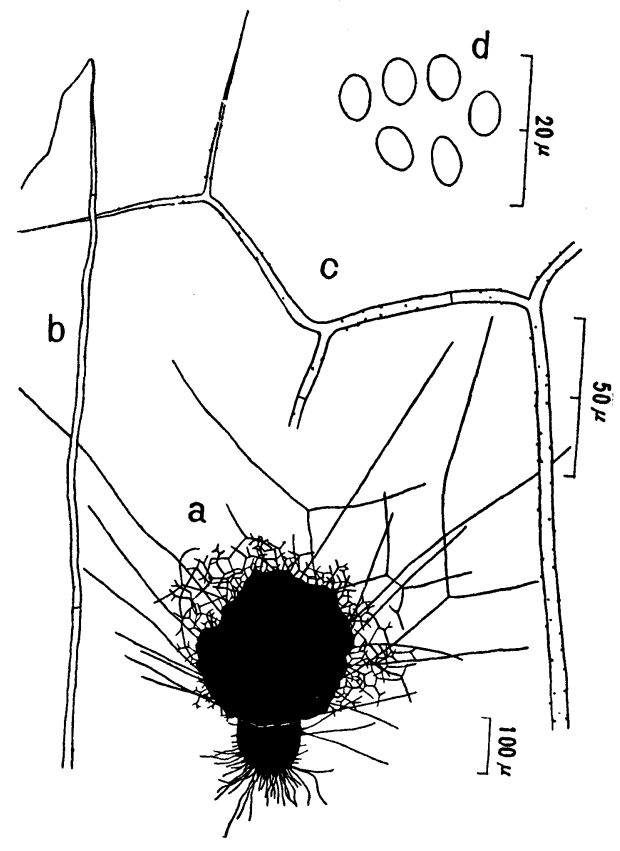

Fig. 17. C. dolichotrichum Ames.

a. Perithecium. b. Unbranched terminal hair. c. Branched terminal hair. d. Ascospores.

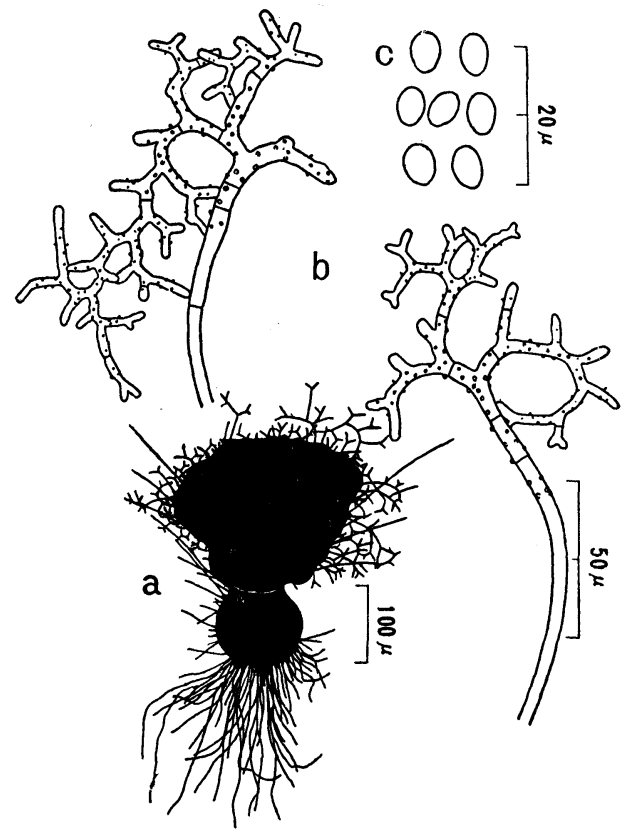

Fig. 18. C. reflexum Skolko et Groves. a. Perithecium. b. Terminal hairs.

c. Ascospores.

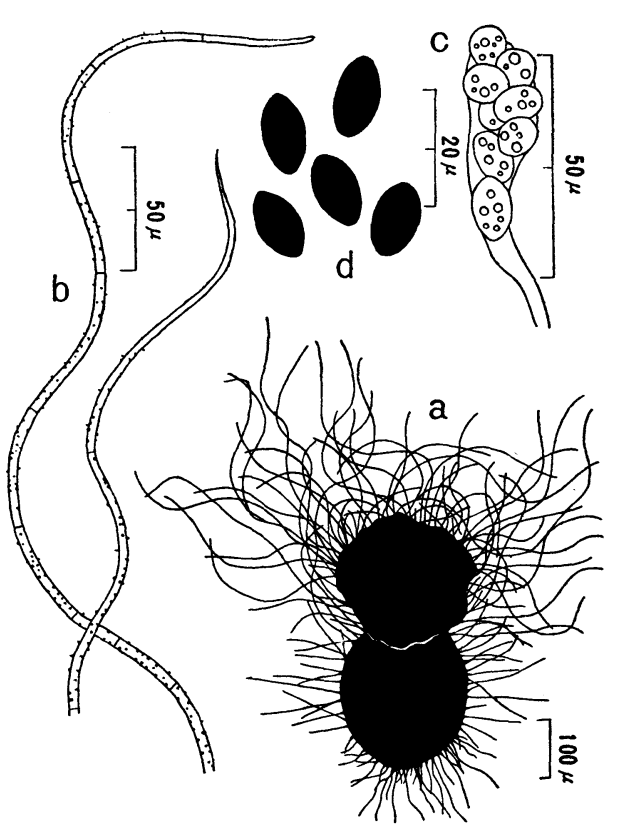

Fig. 19. C. undulatum Bainier.

a. Perithecium. b. Terminal hairs. c. Ascus. d. Ascospores.

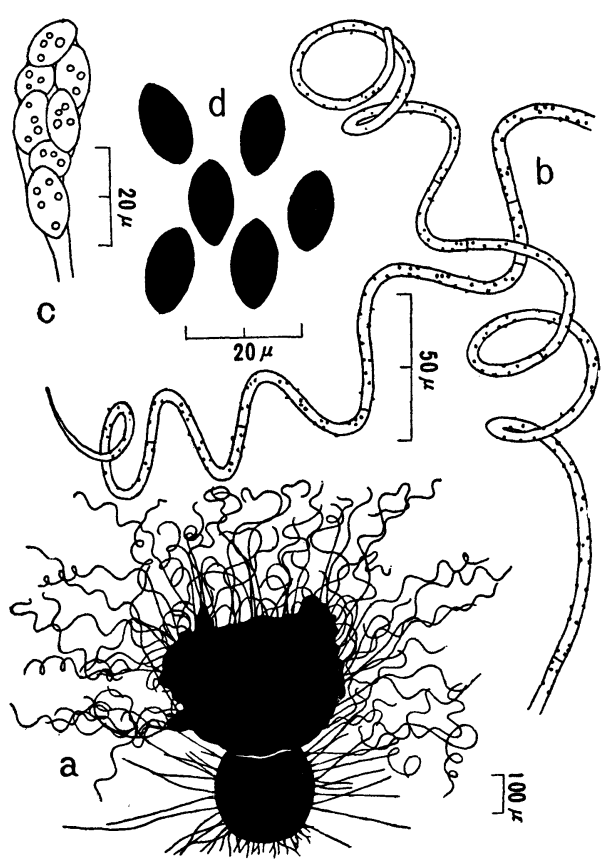

Fig. 20. C. succineum Ames.

a. Perithecium. b. Terminal hairs. c. Ascus. d. Ascospores. 
olive brown, ellipsoid, $11.5-15 \times 7-7.5 \%$, subapiculate at one or both ends.

At $37^{\circ}$, growth is nil.

SPECIMEN EXAmined: Culture from NI, OUT, as Chaetomidium fimeti (NHL 2221).

The findings entirely differ from those of $C$. fimet $i$ which is characterized by short awl-shaped hairs and ovate ascospores. According to CHivers (18), C. undulatum is a synonym of $C$. globosum in the broad sense. This disposition ignores ascospore shape and size, which, if retained as a valid segregating characteristic, prevents such synonymy, since the ascospores of typical C. globosum are lemon-shaped and 8.5-10.5 $\times 7-8.5$ (mostly $9 \times 7.5) \mu$. It seems best here to treat $C$. undulatum as a distinct species. For similar reasons, Sergejeva (36) recently separated $C$. megalocarpum from $C$. globosum. Name$1 \mathrm{y}$, in the former species, the ascospores are globose and $15-16.5 \times 16.5 \mu$.

20. Снаетомium succineum Ames, in Mycologia, 41: 645. 1949; Skolko \& Groves, in Can. J. Botany, 31: 803. 1953. (Fig. 20)

Cultures on cellulose agar growing rapidly, grayish blue green to dark green in age, with the surrounding agar light orange. Perithecia dark olive brown, globose, 230-280 $\mu$ in diam., ostiolate. Terminal hairs dark olive brown, slender, straight or flexed below, mostly ending in 6-8 sinuous, distant coils or sometimes a few large looping coils, 3-4 $\mu$ wide, with tapering or rather blunt tips, delicately roughened, septate. Lateral hairs similar but commonly flexed to sinuous. Asci club-shaped, 8-spored. Ascospores olive green to olive brown, ellipsoid, $13.5-16 \times 6-7.5 \mu$, slightly apiculate at the ends.

At $37^{\circ}$, rapidly growing but sterile.

SPecimen examined: Culture from J. W. Groves (NHL 2258).

Comparative observations of $C$. succineum in different culture media have shown the certain morphological variability of the terminal hairs. In some instances, the terminal hairs are not sinuous, ending in 1-3 large looping coils with untapered blunt tips.

21. Chaetomium ochraceum Tschudy, in Am. J. Botany, 24: 475. 1937; Skolko \& Groves, in Can. J. Botany, 31: 798. 1953. (Figs. 21, 38)

Cultures on cellulose agar spreading broadly, at first yellowish brown, then becoming dark olive gray in age. Perithecia dark olive brown, globose to subglobose, $320-380 \times 300-360 \mu$. Terminal hairs light olive, irregularly undulate to loosely coiled, forming a densely entangled head, gradually tapering to hyaline tip, rarely branched, $1.5-2.5 \mu$ wide, smooth or minutely roughened, obscurely septate. Lateral hairs similar but short, more or less yellowish brown. Asci club-shaped, 8-spored. Ascospores light olive green to olive green, lemon-shaped, $7.5-8.5 \times 5.5-6 \mu$, subapiculate at both ends.

At $37^{\circ}$, growth is nil.

SPecimen examined: Culture from J. W. Groves (NHL 2242).

C. ochraceum is closely related to $C$. globosum from which it differs in the nature of terminal hairs and ascospore size. On cellulose agar, the 
ochraceous mycelium referable to this species is not a significant diagnostic characteristic.

22. Chaetomium quadrangulatum Chivers, in Proc. Am. Acad. Arts Sci., 48: 85. 1912 \& in Mem. Torrey Botan. Club, 14: 202. 1915; Skolko \& Groves, in Can. J. Botany, 31: 799. 1953. (Figs. 22, 39)

Cultures on cellulose agar ( 0.1 per cent yeast extract) spreading broadly, grayish black to black. Perithecia dark olive brown, barrel-shaped, 500-550 $\times$ 250-320 $\mu$, ostiolate. Terminal hairs dark olive, straight below, becoming mostly sinuous or spirally coiled above with few convolutions, occasionally branched at wide angles, rarely straight throughout, with pointed tips, 5.5$6 \mu$ wide at the base, distinctly roughened, septate. Lateral hairs dark olive, straight, tapering and fading to hyaline tip, 4.5-5.5 $\mu$ wide at the base, roughened, septate. Asci club-shaped, 8-spored. Ascospores pale olive, quadrangular, square to slightly rhomboid with rounded corners, 5.5-6 $6 \times 5-6 \mu$ when measured on the diagonals, ovate in side view.

At $37^{\circ}$, growth is nil.

Specimen EXAmined: Culture from J. W. Groves (NHL 2249).

The terminal hairs are slightly narrower than indicated in the original description, but in other features, the present findings agree with those of the type. Ascospore shape is unique among the species in the genus.

23. Снaetomium subspirale Chivers, in Proc. Am. Acad. Arts Sci., 48: 84. 1912 \& in Mem. Torrey Botan. Club, 14: 173. 1915; Skolko \& Groves, in Can. J. Botany, 31: 802. 1953. (Fig. 23)

Cultures on cellulose agar (0.1 per cent yeast extract) rather rapidly growing, dark olive gray. Perithecia later ripened, dark olive brown, barrelshaped, $340-400 \times 220-280 \mu$, ostiolate. Terminal hairs dark olive, straight below, irregularly spirally coiled above with up to 5-8 coils, often elongated or twisted near the apex, minutely roughened, septate, $3-4 \mu$ wide at the base, tapering and fading to hyaline tip. Lateral hairs similar but short, less coiled, 2.5-3 $\mu$ wide at the base. Asci club-shaped, 8-spored. Ascospores dark olive, lemon-shaped, 5.5-6 $\times 4.5-5 /$, apiculate at both ends. Chlamydospores borne laterally or intercalarly on the aerial hyphae, globose to subglobose, $6-7.5 \mu$ in diam., brown, smooth, thick-walled.

At $37^{\circ}$, growth is nil.

SPECimen EXAmined: Culture from J. W. Groves (NHL 2257).

This species is peculiar in having barrel-shaped perithecia, irregularly coiled terminal hairs with elongated or twisted tips, and short coiled lateral hairs.

24. Снaetomium CRispatum Fuckel, Symb. Mycol., p. 90. 1869; Chivers, in Mem. Torrey Botan. Club, 14: 171. 1915; Skolko \& Groves, in Can. J. Botany, 31: 791. 1953. (Figs. 24, 40)

Cultures on cellulose agar (0.1 per cent yeast extract) rather rapidly 


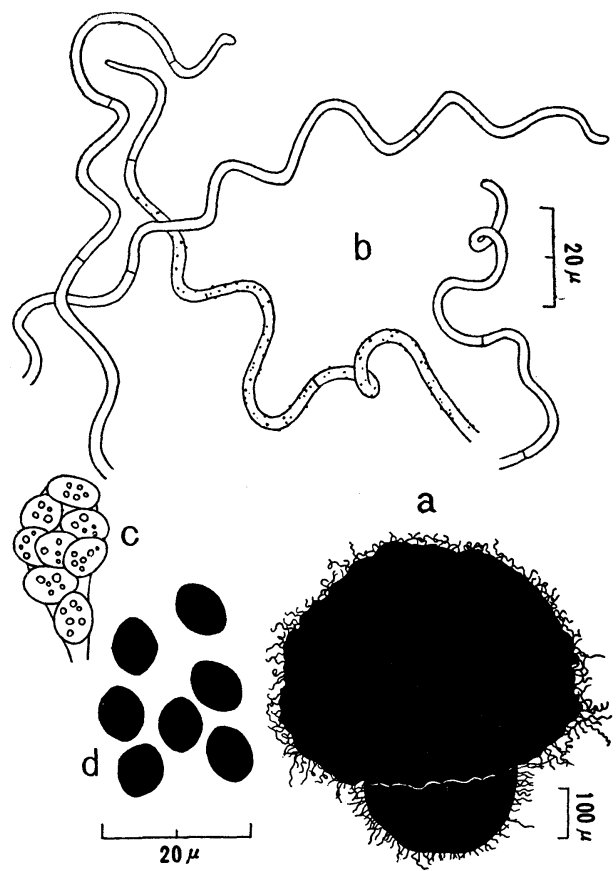

Fig. 21. C. ochraceum Tschudy.

a. Perithecium. b. Terminal hairs. c. Ascus. d. Ascospores.

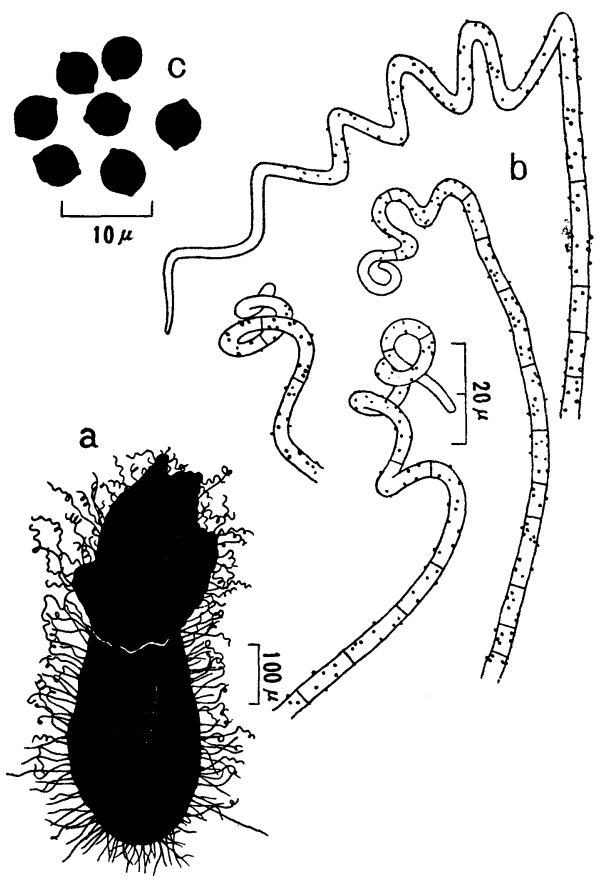

Fig. 23. C. subspirale Chivers. a. Perithecium. b. Terminal hairs. c. Ascospores.

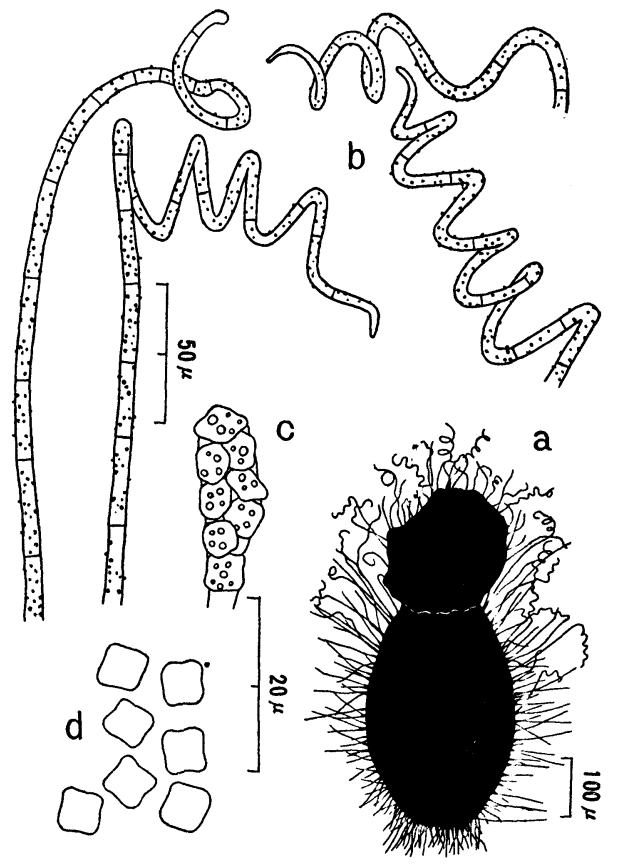

Fig. 22. C. quadrangulatum Chivers.

a. Perithecium. b. Terminal hairs. c. Ascus. d. Ascospores.

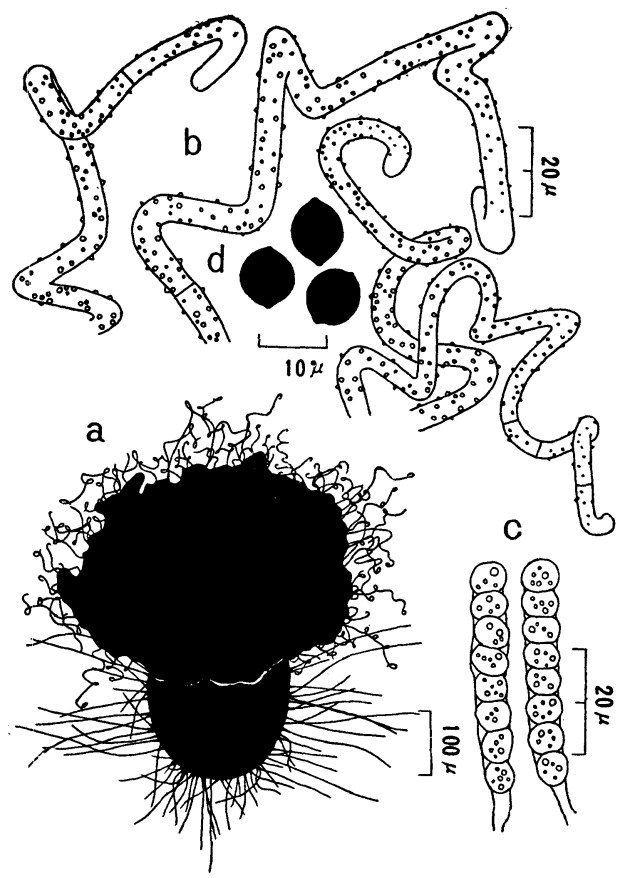

Fig. 24. C. crispatum Fuckel.

a. Perithecium. b. Terminal hairs. c. Asci. d. Ascospores. 
growing, olive gray to dark olive gray, reverse dull yellow with a brown tint. Perithecia dark olive brown, gradually developing, subglobose, 200$280 \times 180-250 \mu$, ostiolate. Terminal hairs olive brown to black, straight below, $3 \mu$ wide at the base, twisting above into reversed loops with short arches, terminating in an incurved blunt tip, 5.5-6 $\mu$ wide at the broadest part of loop, coarsely roughened, septate. Lateral hairs light olive brown, straight, with long, collapsed hyaline tips, $2.5-3 \mu$ wide at the base, finely roughened, septate. Asci cylindrical, 8-spored. Ascospores uniseriate, dark olive brown, lemon-shaped, $8.5-10 \times 7.5-8.5 \mu$, mostly apiculate at both ends.

At $37^{\circ}$, growth is nil.

SPECIMEN EXAMined: Culture from NI (NHL 2124).

The small perithecia and ascospores remind ones of $C$. simile, but, in the terminal hairs, the presence of coarsely roughened loops with short arches excludes it from that species.

\section{SUMMARY}

A taxonomic study of the genus Chaetomium in Japan is prepared under the modern criteria. Twenty-four species are described and illustrated, of which fifteen species are isolated from natural sources in the area. The new species, C. gracile, is described. Eleven species are reported for the first time in Japan. These are $C$. indicum Corda, C. aureum Chivers, $C$. trilaterale Chivers, C. fusiforme Chivers, C. torulosum Bain., C. murorum Corda, C. atrobrunneum Ames, C. olivaceum Cooke et Ell., C. bostrycodes Zopf, C. cochliodes Palliser, and C. spirale Zopf. A key to the species is included.

\section{ACKNOWLEDGEMENTS}

I wish to express my sincere appreciation to Prof. S. Hirayama of the Mie University, to Dr. Y. KobaYAsi of the National Science Museum, and to Dr. H. Tsunoda of the Food Research Institute, for their constant guidances. I am also indebted to Dr. H. Irzuka of the Institute of Applied Microbiology, University of Tokyo, to Mr. H. Kurata of the National Hygienic Laboratory, and to Dr. K. Tubaki of the Nagao Institute, for many valuable suggestions in the preparation of this manuscript.

\section{REFERENCES}

(1) E. T. Reese, H. S. Levinson, and M. H. Downing: Farlowia, 4, 45 (1950).

(2) J. C. Gilman: A Manual of Soil Fungi (2nd Ed.), The Iowa State College Press, Ames, Iowa, 1957, pp. 450.

(3) F. F. NORD and J. C. VITUCCI: Advances in Enzymol., 8, 269 (1948).

(4) R. G. H. SIU: Microbial Decomposition of Cellulose, Reinhold Pub. Co., N. Y., 1951, pp. 531.

(5) R. G. H. Siu and E. T. Reese: Boton. Rev., 19, 377 (1953). 
(6) H. IWAmoto and K. KuRIHARA: Rep. Fermentation Research Inst., 11, 125 (1955) (Japanese).

( 7 ) H. Iwamoto, K. Kurihara, and M. Shiga: ibid., 15, 27 (1958) (Japanese).

(8) S. NIKAI: J. Fermentation Technol., 36, 202 (1958) (Japanese).

( 9 ) D. H. Johnson, A. Robertson, and W. B. Whalley: J. Chem. Soc., 2429 (1953).

(10) H. Nishikawa: J. Fac. Agr. Tottori Univ., 1, 71 (1952).

(11) M. Itahashi, Y. Murakami, and H. Nishikawa: Tohoku J. Agr. Research, 5, 281 (1955).

(12) G. Lloyd, A. Robertson, G. B. Sankey, and W. B. Whalley: J. Chem. Soc., 2163 (1955).

(13) T. A. Rosett: Thesis, Univ. of London, 1955. (cited by C. E. Stickings and H. RAISTRICK: Ann. Rev. Biochem., 25, 225 (1956).)

(14) S. A. WAKSMAN and E. Bugie: J. Bacteriol., 48, 527 (1944).

(15) W. B. GeIger: Arch. Biochem., 21, 125 (1949).

(16) M. T. TVeit: Acta Pathol. Microbiol. Scand., 37, 429 (1955).

(17) K. SaIto and G. OKAzAKI: J. Fermentation Technol., 17, 769 (1939) (Japanese).

(18) A. H. Chivers: Mem. Torrey Botan. Club, 14, 155 (1915).

(19) L. M. AMES: Mycologia, 43, 29 (1951).

(20) R. K. BENJAMIN: ibid., 41, 346 (1949).

(21) G. Lindau: Pyrenomycetineae. (A. Engler and K. Prantl: Die natürlichen Pflanzenfamilien I. Teil, Abt. 1, 321-491 (1897), Leipzig.)

(22) J. A. NAnnfeldt: Nova Acta Regiae Soc. Sci. Upsal., IV, 8, 1 (1932).

(23) H. Greis: Jahrb. für wiss. Botan., 90, 233 (1941).

(24) F. and Mme. Moreau: Rev. Mycol., 19, 167 (1954).

(25) A. Munk: Dansk Botan. Ark., 17, 1 (1957).

(26) R. H. Tschudy: Am. J. Botany, 24, 472 (1937).

(27) G. A. Greathouse and L. M. Ames: Mocologia, 37, 138 (1945).

(28) S. J. Hughes: Brit. mycol. Soc. Trans., 29, 70 (1946).

(29) A. J. Skolko and J. W. Groves: Can. J. Research, C, 26, 269 (1948).

(30) A. J. Skolko and J. W. Groves: Can. J. Botany, 31, 779 (1953).

(31) A. C. Batista and D. Pontual: Bol. Sec. Agr. Ind. Com., Pernambuco, 15, 62 (1948).

(32) L. M. AMES: Mycologia, 41, 637 (1949).

(33) L. M. AMEs: ibid., 42, 642 (1950).

(34) C. J. LA Touche: Brit. mycol. Soc. Trans., 33, 94 (1950).

(35) Aa. OMviK: Mycologia, 47, 748 (1955).

(36) K. S. Sergejeva: Not. syst. Sect. crypt. Inst. botan. Acad. Sci. U.S.S.R., 10, 176 (1955).

(37) K. S. Sergejeva: ibid., 11, 104 (1956).

(38) K. S. Sergejeva: ibid., 11, 108 (1956).

(39) S. J. Hughes: Can. J. Botany, 36, 727 (1958).

(40) W. M. PAGE: Brit. mycol. Soc. Trans., 23, 253 (1939).

(41) W. C. Whiteside: Mycologia, 49, 420 (1957).

(42) M. G. BaInier: Bull. Soc. Mycol. France, 25, 191 (1909).

(43) J. VAN BRUMMELEN and J. C. WENT: Antonie van Leeuwenhoek (J. Microbiol. Serol.), 23, 385 (1957).

(44) W. C. Haynes, L. J. Wickerham, and C. W. Hesseltine: Appl. Microbiol., 3, 361 (1955), 


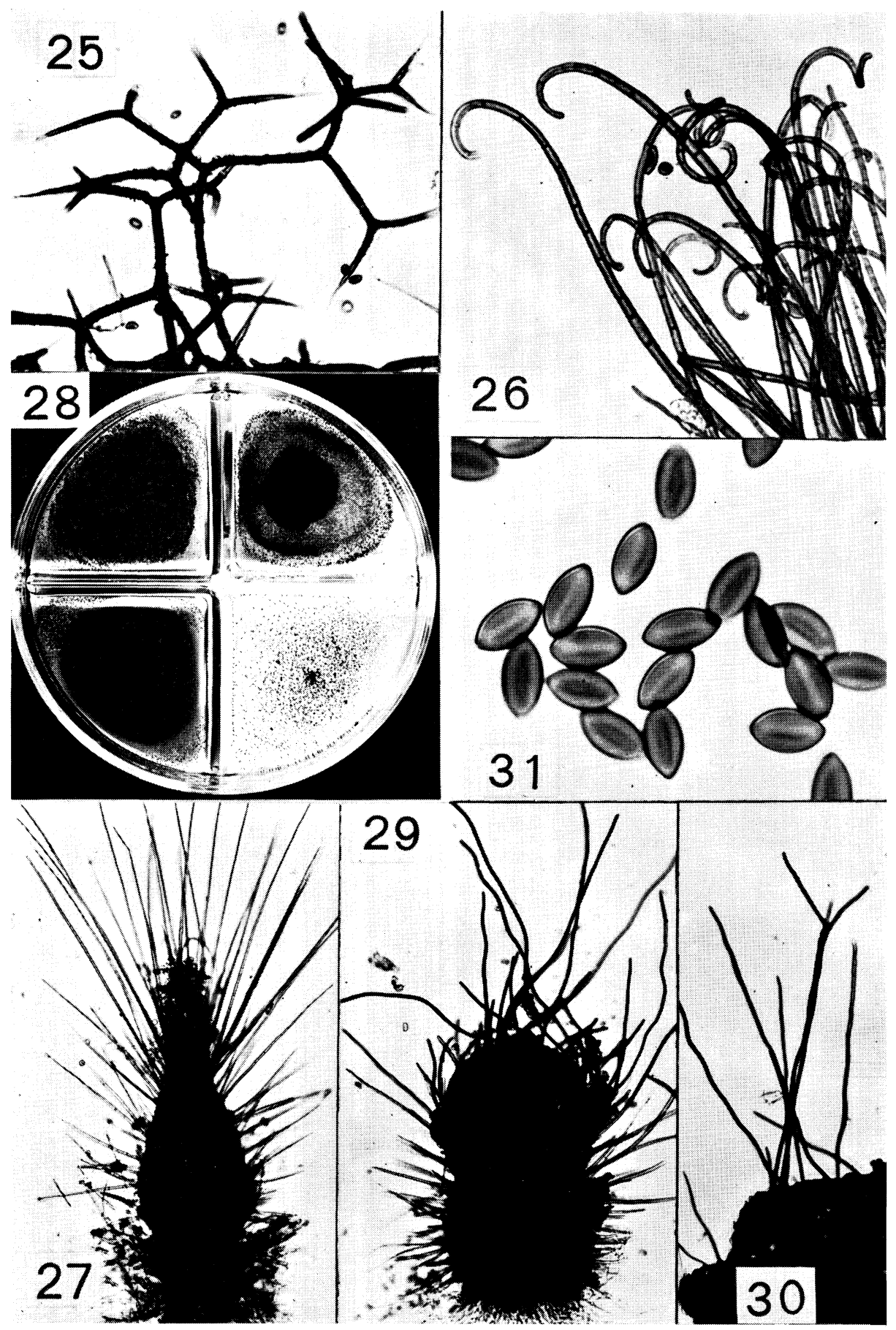

Fig. 25, C. indicum, terminal hairs, $\times 250$. Fig. 26, C. trilaterale, terminal hairs, $\times 300$. Fig. 27, C. torulosum, perithecium, $\times 100$. Figs. 28-31, C. gracile; 28, cultures on laboratory media (yeast extract agar, Czapek agar, potato-dextrose agar and cellulose agar: top left, top right, bottom left and bottom right, respectively) at $25^{\circ}, 3$ weeks; 29 , perithecium, $\times 100 ; 30$, apical portion of terminal hairs, $\times 120 ; 31$. ascospores, $\times 1000$. 


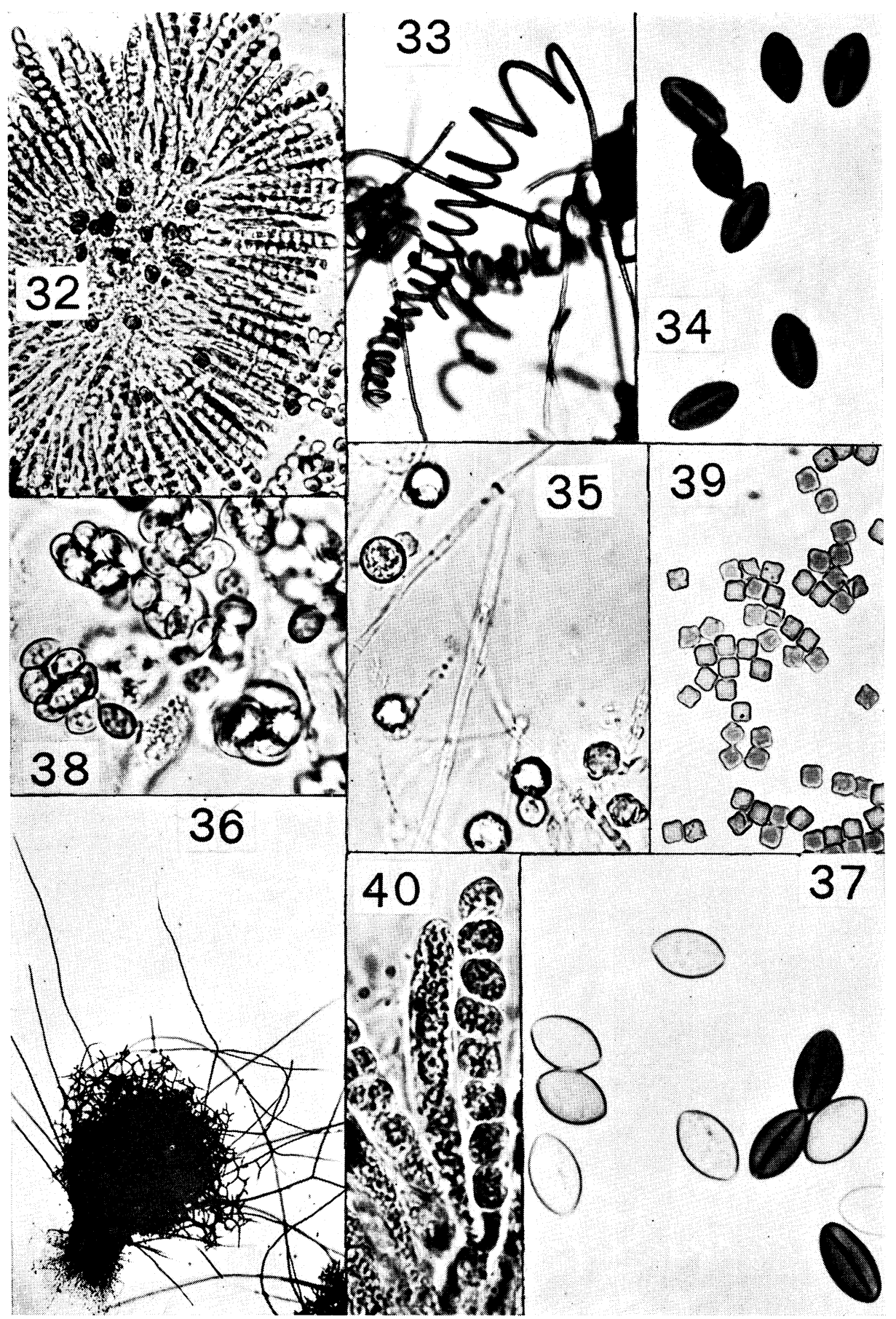

Fig. 32, C. brasiliense, asci, $\times 250$. Figs. $33-35$, C. spirale; 33, terminal hair, $\times 200$; 34 , ascospores, $\times 800$; 35, chlamydospores, $\times 600$. Fig. 36, C. dolichotrichum, perithecium, $\times 60$. Fig. 37, C. undulatum, ascospores, $\times 1000$. Fig. 38, C. ochraceum, asci, $\times 800$. Fig. 39, C. quadrangulatum, ascospores, $\times 600$. Fig. 40 , C. crispatum, asci, $\times 1000$. 
(45) L. Garbowski: Prace Wydz. Chor. Rośl. Państw. Inst. Nauk. Gosp. Wiejsk. Bydgoszczy, 15, 5 (1936).

(46) K. Ramakrishnan: Proc. Indian Acad. Sci. Sect. B, 38, 118 (1953).

(47) H. Krzemieniewska and L. Badura: Acta Soc. Botan. Polon., 23, 727 (1954).

(48) L. A. Beliakova: Bull. soc. naturalistes Moscou, 59, 85 (1954).

(49) A. E. TraAen: Nyt Mag. Naturvid., 19 (1914). (cited by P. A. Saccardo: Syll. Fung., 24, 240 (1926).)

(50) F. H. van Beyma: Antonie van Leeuwenhoek (J. Microbiol. Serol.), 10, 41 (1944).

(51) M. E. SwIFT: Mycologia, 21, 204 (1929).

(52) H. L. Palliser: N. Am. Flora, 3, 59 (1910). 